\title{
iRhom2: An Emerging Adaptor Regulating Immunity and Disease
}

\author{
Mazin A. Al-Salihi ${ }^{\circ}$ and Philipp A. Lang * \\ Department of Molecular Medicine II, Medical Faculty, Heinrich-Heine-University Düsseldorf, \\ Universitätsstrasse 1, 40225 Düsseldorf, Germany; alsalihi@hhu.de \\ * Correspondence: langp@uni-duesseldorf.de
}

Received: 30 July 2020; Accepted: 2 September 2020; Published: 8 September 2020

\begin{abstract}
The rhomboid family are evolutionary conserved intramembrane proteases. Their inactive members, iRhom in Drosophila melanogaster and iRhom1 and iRhom 2 in mammals, lack the catalytic center and are hence labelled "inactive" rhomboid family members. In mammals, both iRhoms are involved in maturation and trafficking of the ubiquitous transmembrane protease a disintegrin and metalloprotease (ADAM) 17, which through cleaving many biologically active molecules has a critical role in tumor necrosis factor alpha (TNF $\alpha$ ), epidermal growth factor receptor (EGFR), interleukin-6 (IL-6) and Notch signaling. Accordingly, with iRhom2 having a profound influence on ADAM17 activation and substrate specificity it regulates these signaling pathways. Moreover, iRhom 2 has a role in the innate immune response to both RNA and DNA viruses and in regulation of keratin subtype expression in wound healing and cancer. Here we review the role of iRhom 2 in immunity and disease, both dependent and independent of its regulation of ADAM17.
\end{abstract}

Keywords: iRhom2; Rhbdf2; ADAM17; TACE; ectodomain shedding; EGFR; TNF; MAVS; STING

\section{Introduction}

Rhomboids are an evolutionarily conserved family of multi-span transmembrane proteins [1]. Some are catalytically active serine proteases capable of intramembrane cleavage of their substrates. These were originally discovered in Drosophila melanogaster as intramembrane proteases of EGFR ligands [2-5]. Other rhomboid family members, while structurally similar, are catalytically inactive and known as pseudoproteases. These rhomboid pseudoproteases were nonetheless found to be evolutionarily conserved indicating the presence of selective pressure despite absence of their proteolytic activity [6]. This alludes to functions beyond rhomboid catalytic activity that are important enough to be preserved. iRhoms 1 and 2, encoded by the genes Rhbdf 1 and 2, belong to the latter family of pseudoproteases. They were named iRhoms to indicate their proteolytic inactivity while being part of the rhomboid family [7].

Both Drosophila and mammalian iRhoms bind their partner proteins in the ER. Drosophila's single iRhom interacts with EGF family ligands resulting in ER associated ligand degradation (ERAD) and inhibition of EGFR signaling [8]. However, the two mammalian iRhoms bind to ADAM17 rather than the EGFR ligands, which results in trafficking of ADAM17 to the Golgi where it can begin its post-translational modification journey to become a cell surface active protease. Furthermore, iRhom 2 is reported to be involved in immune responses seemingly unrelated to ADAM17 activity $[9,10]$. There are excellent reviews on iRhom and ADAM17 structure [11], functional regulation and expression patterns [12], cellular and pathophysiological roles as well as novel binding partners [13] and combined biological functions [14]. This review however will focus on iRhom2, both as a regulator of ADAM17 as well as its ADAM17-independent roles in immunity and disease. 


\section{Regulation of ADAM17 by iRhom2}

Understanding the journey of ADAM17 from production to function is central to understanding how iRhoms modulate ADAM17 activity. Ectodomain shedding of cell surface transmembrane proteins plays a central role in several signaling pathways such as the EGFR and TNF pathways. These cleavage events are performed by metalloproteases, such as ADAM17, also known as TNF $\alpha$ converting enzyme (TACE) in reference to the original discovery of its role in TNF $\alpha$ shedding [15-17]. ADAM17 can shed a variety of ligands including the adhesion molecule L-selectin, transforming growth factor alpha (TGF $\alpha$ ), the IL-6 receptor (IL-6R) as well as the TNF $\alpha$ receptors (TNFR) 1 and 2 themselves [18,19]. These and a list of over 80 biologically active molecules shed by ADAM17, including growth factors, cytokines, receptors and adhesion molecules are involved in a wide array of physiological processes and diseases from innate immune responses to carcinogenesis [20]. Therefore, it is not surprising that ADAM17 is regulated on multiple levels as briefly summarized here to highlight the interactions with iRhom2 (Figure 1), while a detailed description of these mechanisms have been reviewed elsewhere [12,20].

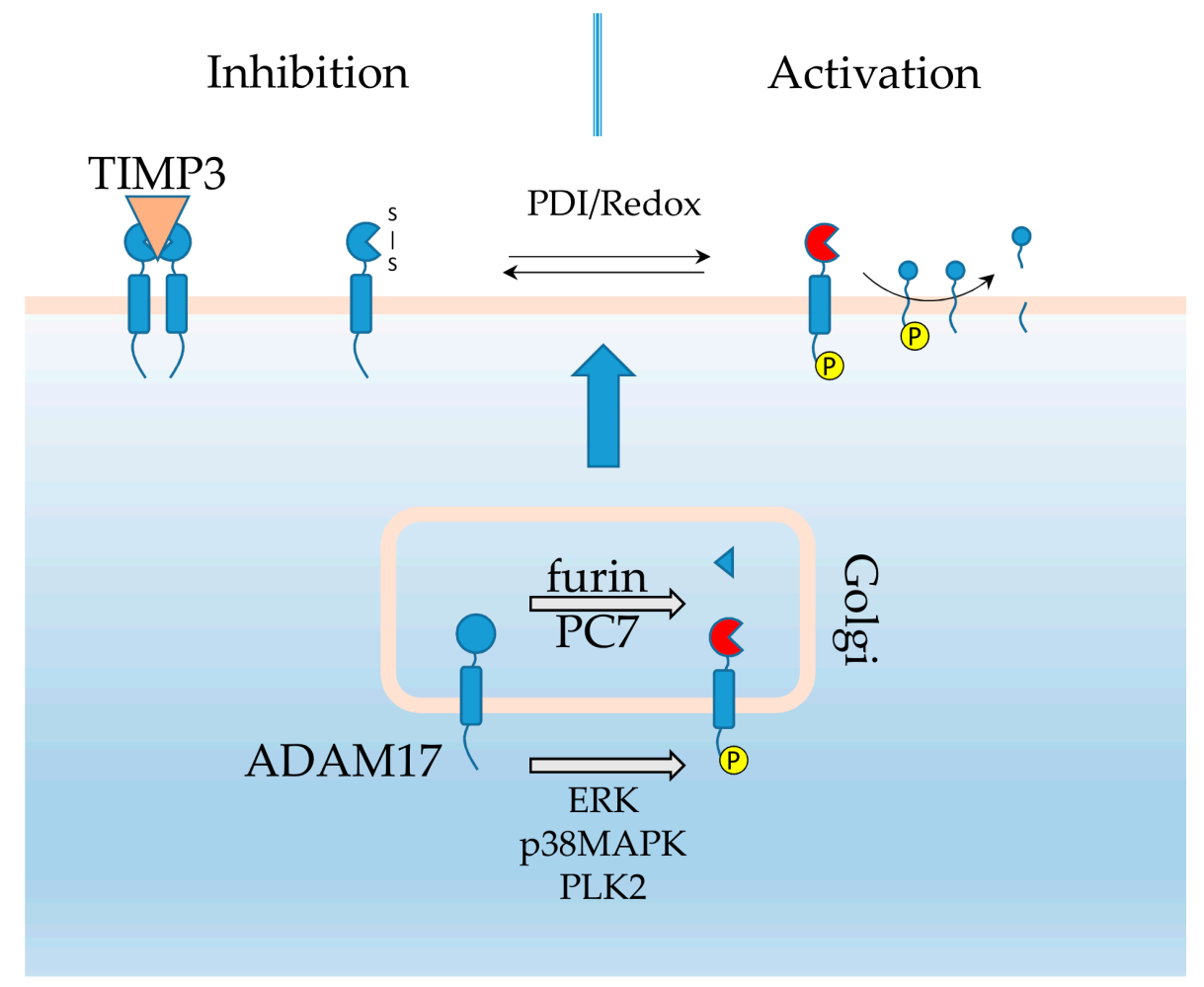

Figure 1. ADAM17 post translational regulation. ADAM17 is processed in the Golgi to remove its inhibitory pro-domain. Its cytoplasmic tail is phosphorylated, but that is not required for its transport from the Golgi to the cell surface. However, when not phosphorylated this induces ADAM17 dimerization and TIMP3 binding resulting in inactivation. Alteration in the disulfide bridge arrangements can also alter ADAM17's activation status. The phosphorylation status of the substrates themselves can also alter ADAM17 shedding performance.

Once produced, ADAM17 requires several post-translational modifications to become catalytically active. It is proteolytically processed in the Golgi by the proprotein-convertases PC7 and furin to remove its inhibitory pro-domain [21-23]. Its cytoplasmic tail is phosphorylated by extracellular signal-regulated kinases (ERK) and mitogen activated protein kinases (MAPK) as part of protein kinase C (PKC) signaling activity, as well as by Polio like kinase 2 (PLK2) [24-31]. Phosphorylation of ADAM17's cytoplasmic tail, or its deletion, is required for ADAM17 proteolytic activity as well as its trafficking to the cell surface [32]. Unless phosphorylated, the tail serves to dimerize ADAM17 which in turn allows tissue inhibitor of metalloprotease 3 (TIMP3) to bind and inhibit ADAM17 
activity. Therefore, deletion or phosphorylation of the cytoplasmic tail allows ADAM17 to become catalytically active [33-36]. Moreover, ADAM17 substrate phosphorylation has also been reported to influence its ability to shed these post-translationally modified substrates $[28,37]$. At the cell surface, alteration in the intramolecular disulfide bridge status of ADAM17 by disulfide isomerases, or in response to changes in the local redox environment such as during inflammatory events, induces a conformational change regulating ADAM17 activity as well [38-42]. The ADAM17-iRhom1 and iRhom2 interaction governs ADAM17's maturation, trafficking towards the cell surface and even its proteolytic activity and substrate selectivity [43-49]. While ADAM17 has been reported to stabilize cell surface iRhom2 in return [50]. Similar to ADAM17 iRhom2 levels are regulated transcriptionally. iRhom 2 is a p63 transcription factor target gene in keratinocytes [51], is induced in response to exposure to lipopolysaccharides (LPS) or viral infections in macrophages $[9,43,44]$ and induced in the liver post bile duct ligation [52]. It may also be regulated through proteasomal mediated degradation. Its half-life can be extended by treating cells with the proteasomal inhibitor MG-132 [53]. However, direct evidence of $k 48$ ubiquitination and proteasomal degradation is still lacking.

Once produced both iRhom1 and iRhom 2 bind directly to ADAM17 [49]. The ADAM17-iRhom2 interaction was originally elucidated in relation to ADAM17 shedding of TNF $\alpha$ in hematopoietic cells in iRhom 2 deficient mice $[43,44]$. This interaction was shown to be specific to ADAM17 and not its closest relative ADAM10 [43]. A panel of other ADAM proteins were also tracked in double iRhom 1 \& 2 knock out fibroblasts; none of which were found to traffic differently in the absence of iRhoms [49]. The iRhom 2 loss of function sincere $(\sin )$ mutation provided more nuanced insights into the complete mechanism of iRhom-ADAM17 regulation. The sin mutation is present in iRhom2's first transmembrane helix and results in reduced TNF $\alpha$ shedding [54]. It was later identified that the transmembrane helices of iRhom2 interact with ADAM17 [46,55], with the sin mutation disrupting that interaction and resulting in iRhom2's inability to traffic ADAM17 efficiently out of the ER and into the Golgi [55]. The sin mutation also affected ADAM17's substrate selectivity [55].

The same mechanism was later extended to ADAM17 shed EGFR ligands as well [53,56]. iRhom2 gain of function mutations in its $\mathrm{N}$-terminal cytoplasmic tail, identified in the inherited Tylosis with oesophageal cancer (TOC) syndrome, result in increased EGFR ligand shedding and subsequent activation of EGFR signaling (Box 1) [57-59]. The same TOC gain of function mutations were also found to enhance shedding of TNFRs [60]. Consistently, two studies employing the same mouse curly bare (cub) iRhom 2 mutation which deletes most of the cytoplasmic domain showed alterations in EGFR signaling [53,56]. Mechanistically, iRhom 2 mediates ADAM17 trafficking and its subsequent activation which results in enhanced ADAM17 shedding activity (Figure 2) [45-47,49,61-65].

iRhom 2 was found to efficiently bind mature ADAM17, and over-expressed iRhoms were found to localize to the plasma membrane, indicating a continued relationship at the cell surface $[43,60,66]$. Furthermore, ADAM17 substrate shedding differs depending on which of the two iRhoms is present [45]. This selectivity was recently shown to be regulated through direct iRhom-ADAM17 interaction via both their transmembrane helices and juxta-membrane domains, confirming their continued interaction at the cell surface [46]. However, for ADAM17 to actually shed its target substrates it needs to be at least momentarily relieved from iRhom binding [66,67]. In a similar fashion to ADAM17 regulation iRhoms are also regulated by post-translational modifications and protein-protein interactions, adding a further layer of control to the iRhom-ADAM17 relationship. ERK and MAPK-dependent phosphorylation of the cytoplasmic tail of iRhom2 results in 14-3-3 proteins binding to iRhom 2 and its dissociation from ADAM17, which in turn allows stimulated shedding of ADAM17 targets [66,67]. Furthermore, and similar to control of ADAM17 activity through its cytoplasmic tail, this phosphorylation event has no effect on iRhom 2 mediated ADAM17 maturation, and removal of the cytoplasmic tail altogether actually increased constitutive ADAM17 shedding activity of TNFR [60]. This indicates that direct cell surface phosphorylation controls iRhom-ADAM17 stimulated shedding. Further cementing the combined control of both proteins on the cell surface through their cytoplasmic tails, iRhom 2 cytoplasmic tail binding partners also have a considerable effect on ADAM17 activity. Two groups published 
simultaneously that the four-point-one, ezrin, radixin, moesin (FERM) domain-containing protein 8 (FRMD8), also named the iRhom Tail-Associated Protein (iTAP), stabilizes the iRhom-ADAM17 complex at the cell surface. In its absence ADAM17 shedding of TNF $\alpha$ and EGFR ligands is impaired and the iRhom-ADAM17 complex is endocytosed and degraded in the lysosome [68,69].

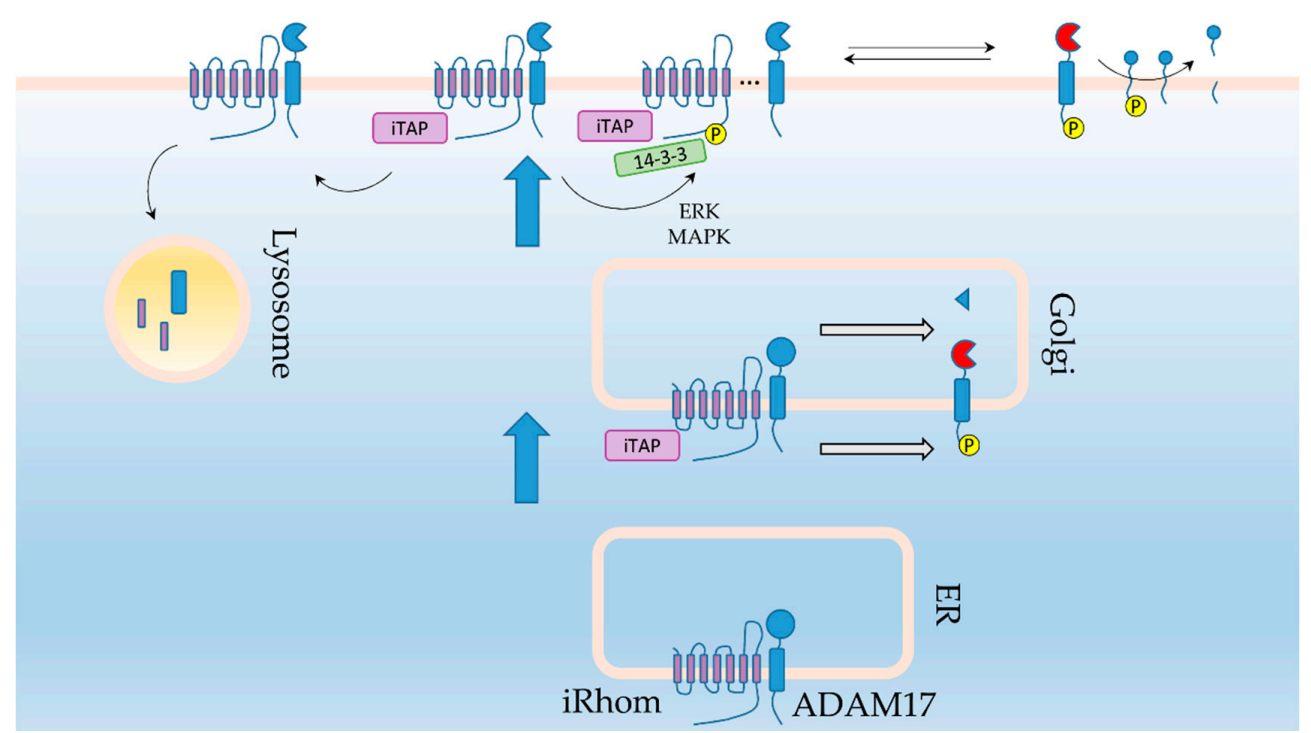

Figure 2. iRhom regulation of ADAM17. iRhom binds to ADAM17 in the ER facilitating its export to the Golgi where it can begin its posttranslational modification fueled activation. iRhom and ADAM17 continue to the cell surface where in the presence of iTAP the complex is stabilized. In its absence the complex is sent for endocytosis and lysosomal degradation. Phosphorylation of iRhom by ERK and MAPK allows iRhom to bind to 14-3-3 proteins, which in turn facilitate release of ADAM17 from the complex to allow final activation and shedding of its targets.

As iRhom2 regulates EGFR ligand shedding, one would expect that the iRhom2 null mice share a similar open eye phenotype seen in EGFR and ADAM17 null mice [18,70]. This is not the case despite iRhom 2 being expressed in the skin. iRhom 2 deficient mice appear healthy, viable, and show no gross phenotype, while ADAM17 deficient mice exhibit severe symptoms after birth [18]. However, iRhom 1 and 2 double knockout mice show similar phenotypes compared to ADAM17 and EGFR null phenotypes, indicating redundancy in the cellular functions of the two iRhoms $[48,49]$. Indeed, iRhom1 triggers shedding of a selection of ADAM17 substrates in mouse embryonic fibroblasts [48]. Moreover, tissue- or cell type- specific expression of iRhom 1 and iRhom 2 might compensate for loss of one iRhom protein. iRhom1 seems to be important in neuronal tissue, excluding microglia $[8,48,71-73]$, while iRhom 2 may have more of a functional role in immune cells including brain microglia and liver hepatic stellate cells $[48,52,54,61]$.

\section{3. iRhom2 Regulated Pathways}

\subsection{TNF Signaling}

$\mathrm{TNF} \alpha$ is the founding member of a superfamily of cytokine-like molecules. Along with their cognate receptors, the TNF receptor (TNFR) superfamily, they control survival, proliferation and pro-inflammatory functions on both immune and non-immune cells [74]. TNF $\alpha$ binding to TNFR1 results in formation of two distinct complexes with diverging functions based on the cellular context; complexes I and II. Complex I consists primarily of the receptor itself, the adaptor protein TNFR1-associated death domain (TRADD), TNFR-associated factor 2 (TRAF-2), cellular inhibitors of apoptosis 1 and 2 (cIAP1/2), linear ubiquitin chain assembly complex (LUBAC) and receptor-interacting 
serine/threonine-protein kinase 1 (RIPK1). Based on the phosphorylation and ubiquitination status of RIPK1, this complex can activate downstream NF- $\mathrm{KB}$ signaling resulting in the expression of pro-inflammatory and pro-survival genes [75-78]. However, if NF-kB dependent transcription is inhibited or RIPK1 phosphorylation and ubiquitination status is changed this will alternatively result in formation of complex II $[79,80]$. Complex II, which is actually 3 distinct sub complexes a-c, results in cell death. Complexes IIa and Ilb induce apoptosis, are caspase 8 dependent and contain either TRADD or RIPK1 respectively, while complex IIc, also known as the necrosome, depends on RIPK1, 3 and mixed lineage kinase domain-like (MLKL) to induce necroptosis $[74,75,81]$.

TNFR1 is ubiquitously expressed and can be activated by both shed and membrane bound TNF $\alpha$. TNFR2 on the other hand is expressed in a more limited fashion on immune, neuronal, cardiac, endothelial and stem cells binding membrane bound TNF $\alpha$ with higher affinity [74]. TNFR2 does not contain a death domain like TNFR1, however its signaling can result in cell death by loss of TRAF2. Mostly its activation induces NF- $\mathrm{kB}$ signaling resulting in more tissue regeneration and repair $[74,82,83]$. TNF $\alpha$ and both of TNFR $1 \& 2$ are shed by ADAM17 under regulation of iRhom $2[15,16,43-45,60,84]$. However, the effect of iRhom 2 on shedding of ADAM17 ligands-specifically, TNF $\alpha$-versus TNFR shedding - can have opposing consequences. The outcome is context specific and depends on the cellular composition and pathophysiological mechanisms within each tissue (Figure 3).

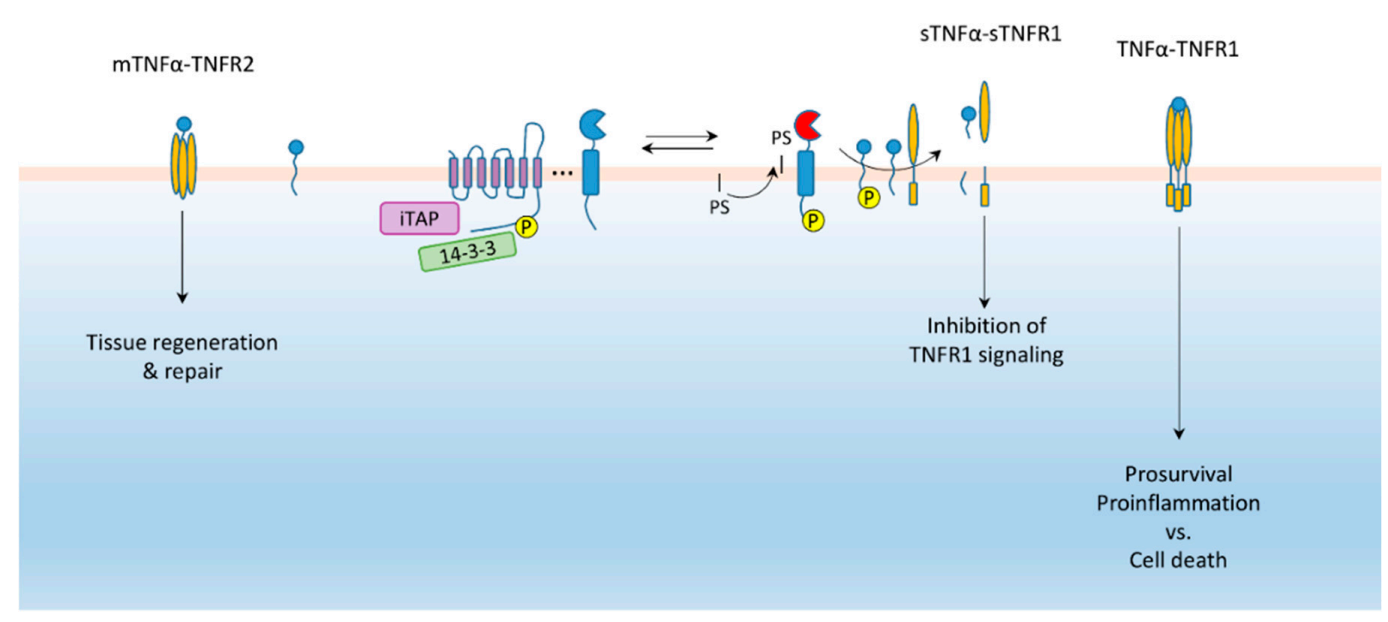

Figure 3. iRhom-ADAM17 regulation of TNF signaling. TNFR1 signaling depends on whether TNF $\alpha$ or TNFR1 is predominantly cleaved. In the absence of TNF $\alpha$ cleavage TNFR2 signaling is favored.

iRhom 2 null mice and those with the sin mutation, that inhibits iRhom2's ability to efficiently traffic ADAM17 from the ER to the Golgi, have reduced soluble TNF $\alpha$ (Table 1) $[43,44,54]$. The TNF $\alpha$-TNFR1 pathway is crucial for bacterial defense [85-88]. Mice with reduced soluble TNF $\alpha$ due to iRhom2 absence succumbed to sublethal doses of Listeria monocytogenes [44]. They were also more likely to develop severe disease after myocardial infarction due to altered TNF $\alpha$ signaling and macrophage polarization [89], and were more likely to develop atherosclerosis when challenged with a high fat diet, although the effect was not solely due to altered TNF $\alpha$ [90]. However, this is at odds with a report of increased TACE expression and TNF $\alpha$ in localized samples of ruptured plaques in human acute myocardial infarction, which also indicates a more complex process beyond TNF $\alpha$ shedding alone [91]. Furthermore, iRhom 2 null mice are more likely to develop fibrosis post bile duct ligation, as a model of human cholestatic disease, due to reduced TNFR1 shedding from the surface of hepatic stellate cells and subsequent enhanced TNF signaling [52]. The same mice conversely are protected from LPS induced septic shock [44], rheumatoid arthritis [61,92], hemophilic arthropathy [93], lupus nephritis [64], post intestinal ischaemia reperfusion acute lung injury [94], renal injury from particulate matter [95] and inflammatory bowel disease [96], all of which are TNF $\alpha$ mediated with the exception 
of lupus nephritis which is TNF $\alpha$ and HB-EGF mediated [64]. A previous study shows the iRhom2 null mice being more susceptible to inflammatory bowel disease using a spontaneous colitis mouse model relating it to altered $\mathrm{T}$ helper cell cytokine production [97].

Table 1. iRhom 2 regulated pathways in immunity and disease.

\begin{tabular}{|c|c|c|c|}
\hline Pathway & $\begin{array}{l}\text { Immune process/ } \\
\text { Disease }\end{array}$ & Mechanism & References \\
\hline \multirow{4}{*}{ EGFR } & $\begin{array}{l}\text { Tylosis with oesophageal } \\
\text { cancer }\end{array}$ & $\begin{array}{l}\text { Activating iRhom2 mutation, increased EGFR ligand } \\
\text { shedding }\end{array}$ & {$[57-59,98-103]$} \\
\hline & $\begin{array}{l}\text { Increased squamous cell } \\
\text { carcinoma }\end{array}$ & $\begin{array}{l}\text { iRhom expression induction, increased EGFR ligand } \\
\text { shedding, increased MET signaling }\end{array}$ & [47] \\
\hline & Increased cervical cancer & $\begin{array}{l}\text { Increased iRhom expression, increased EGFR, WNT } \\
\text { and TGF } \beta \text { signaling }\end{array}$ & [65] \\
\hline & $\begin{array}{l}\text { Lupus nephritis } \\
\text { resistance }\end{array}$ & Reduced iRhom2, soluble TNF $\alpha$ and HB-EGF & [64] \\
\hline \multirow{2}{*}{ K6/16 } & $\begin{array}{l}\text { Tylosis with oesophageal } \\
\text { cancer \& keratinocyte } \\
\text { skin homeostasis }\end{array}$ & $\begin{array}{l}\text { TOC mutated iRhom2 binds K16 altering K6-K16 } \\
\text { dimerization. Reduced iRhom2, reduced K16 } \\
\text { expression. }\end{array}$ & [104] \\
\hline & $\begin{array}{l}\text { Increased oral squamous } \\
\text { cell carcninoma }\end{array}$ & $\begin{array}{l}\text { Increased iRhom } 2 \text { expression, migration and } \\
\text { proliferation }\end{array}$ & [105] \\
\hline \multirow{14}{*}{ TNF } & $\begin{array}{l}\text { Resistance to LPS } \\
\text { induced septic shock }\end{array}$ & Reduced iRhom2,soluble TNF $\alpha$ and TNFR1 signaling & {$[43,44]$} \\
\hline & Bacterial defense defect & Reduced iRhom2,soluble TNF $\alpha$ and TNFR1 signaling & [44] \\
\hline & $\begin{array}{l}\text { Chronic inflammation \& } \\
\text { reduced healing }\end{array}$ & $\begin{array}{l}\text { Induction of iRhom2 expression resulting in reduced } \\
\text { membrane TNF } \alpha \text {-TNFR2 signaling }\end{array}$ & [62] \\
\hline & $\begin{array}{l}\text { Rheumatoid arthritis } \\
\text { resistance }\end{array}$ & Reduced iRhom 2 and soluble TNF $\alpha$ & {$[61,92]$} \\
\hline & $\begin{array}{l}\text { Increased regulatory } \mathrm{T} \\
\text { cell expansion }\end{array}$ & $\begin{array}{l}\text { Reduced iRhom2, increased membrane } \\
\text { TNF } \alpha \text {-TNFR2 signaling }\end{array}$ & [106-109] \\
\hline & $\begin{array}{l}\text { Inflammation \& } \\
\text { hepatoprotection }\end{array}$ & $\begin{array}{l}\text { Induction of iRhom2 expression, increased TNFR } \\
\text { shedding, reduced TNFR1 signaling }\end{array}$ & {$[84,110]$} \\
\hline & $\begin{array}{l}\text { Worsened atherosclerosis } \\
\& \text { myocardial infarction } \\
\text { outcomes }\end{array}$ & $\begin{array}{l}\text { Reduced iRhom2, altered TNF signaling and } \\
\text { macrophage polarization }\end{array}$ & {$[89,90]$} \\
\hline & $\begin{array}{l}\text { Hemophilic arthropathy } \\
\text { resistance }\end{array}$ & Reduced iRhom 2 and soluble TNF $\alpha$ & [93] \\
\hline & $\begin{array}{l}\text { Lupus nephritis } \\
\text { resistance }\end{array}$ & Reduced iRhom2, soluble TNF $\alpha$ and HB-EGF & [64] \\
\hline & $\begin{array}{l}\text { Intestinal ischaemia } \\
\text { reperfusion acute lung } \\
\text { injury resistance }\end{array}$ & Reduced iRhom 2 and soluble TNF $\alpha$ & [94] \\
\hline & $\begin{array}{l}\text { Particulate matter Renal } \\
\text { injury resistance }\end{array}$ & Reduced iRhom 2 and soluble TNF $\alpha$ & [95] \\
\hline & $\begin{array}{l}\text { Inflammatory bowel } \\
\text { disease resistance }\end{array}$ & Reduced iRhom 2 and soluble TNF $\alpha$ & [96] \\
\hline & $\begin{array}{l}\text { Inflammatory bowel } \\
\text { disease susceptibility }\end{array}$ & $\begin{array}{c}\text { Reduced iRhom } 2 \text { and IL10 resulting in altered T } \\
\text { helper cell cytokine production }\end{array}$ & [97] \\
\hline & $\begin{array}{l}\text { Increased cholestatic } \\
\text { liver fibrosis }\end{array}$ & $\begin{array}{l}\text { Reduced iRhom2, reduced TNFR1 shedding in } \\
\text { hepatic stellate cells and increased TNFR1 signaling }\end{array}$ & [52] \\
\hline \multirow[b]{2}{*}{ Notch signaling } & $\begin{array}{l}\text { Hepatocellular } \\
\text { carcinoma induction }\end{array}$ & $\begin{array}{l}\text { Increased iRhom } 2 \text { activity by inducible nitric oxide } \\
\text { synthase, ADAM17 cleavage of Notch receptor }\end{array}$ & [111] \\
\hline & $\begin{array}{l}\text { Reduced hair } \\
\text { development }\end{array}$ & $\begin{array}{l}\text { Spontaneous iRhom } 2 \text { mutation, reduced ADAM17 } \\
\text { activity and Notch receptor processing }\end{array}$ & {$[112,113]$} \\
\hline \multirow{2}{*}{ MAVS \& STING } & $\begin{array}{l}\text { Defective innate immune } \\
\text { response to RNA viruses }\end{array}$ & $\begin{array}{c}\text { Reduced iRhom2, increased E3 ubiquitin ligase, } \\
\text { reduced MAVS by increased proteasomal } \\
\text { degradation }\end{array}$ & [10] \\
\hline & $\begin{array}{l}\text { Defective innate immune } \\
\text { response to DNA viruses }\end{array}$ & $\begin{array}{l}\text { Reduced iRhom2, reduced STING nuclear } \\
\text { translocation \& increased proteasomal degradation }\end{array}$ & {$[9,114]$} \\
\hline
\end{tabular}


Accordingly, there may likely be more nuances to iRhom2's role in inflammatory bowel disease as yet undiscovered, especially that iRhom $2 \mathrm{~T}$ cell modulation has been reported elsewhere. Adoptive transfer of iRhom 2 null $\mathrm{CD} 88^{+} \mathrm{T}$ cells into CD8 null mice with an ongoing viral infection resulted in a greater expansion of the immunosuppressive $\mathrm{V} \beta 5+$ regulatory $\mathrm{T}$ cells (Tregs), indicative of increased membrane TNF $\alpha$-TNFR2 signaling [106-109]. iRhom 2 null mice do indeed have increased presence of unprocessed membrane bound TNF $\alpha$ on their $\mathrm{CD}^{+} \mathrm{T}$ cells [106]. Conversely, increased iRhom 2 expression in chronic inflammation results in enhanced membrane TNF $\alpha$ cleavage from endothelial cells. This results in reduced membrane TNF $\alpha$-TNFR2 signaling to the detriment of the healing process [62]. Finally, increased TNFR shedding under inflammatory conditions, in response to increased iRhom 2 and TACE phosphorylation, protects hepatocytes through reduced TNFR1 signaling and soluble TNFRs binding circulating TNF $\alpha[84,110]$. Hence, depending on the cellular tissue composition in the disease process and the equilibrium of TNF $\alpha$ shedding vs its receptors, the outcome of iRhom 2 regulation of TNF signaling varies greatly.

\subsection{EGFR Signaling}

EGFR, also known as ErbB-1, is a member of a family of four transmembrane tyrosine kinase receptors. It is activated through binding of its ligands to the extracellular domain, which leads to dimerization, trans-autophosphorylation, internalization and either recycling or degradation of the receptors dependent on ligand binding affinity and duration. This results in ligand specific activation of genes responsible for cell proliferation, migration, survival, and differentiation [115]. Signaling pathways activated by EGFR include MAPK, PI3K/AKT, JAK/STAT, and PKC [115-118]. The EGFR ligands can be membrane bound and shed by ADAM10 and ADAM17 [115,119]. Of the seven ligands, amphiregulin (AR), heparin-binding-EGF-like growth factor (HB-EGF), epiregulin (EPR), TGF $\alpha$ and epigen have been reported to be shed by ADAM17 [115,119,120]. EGFR signaling is required for normal epithelial development and homeostasis, as is evidenced by several mouse knock out models. In addition to the open eye phenotype, EGFR deficient mice exhibit developmental defects in several organs including skin, lung and gastrointestinal tract [70]. Furthermore, several epithelial cancers are characterized by enhanced EGFR activation [115,121-124]. This correlates with a poor response to conventional therapy $[125,126]$. Increased EGFR signaling in epithelial cancers occurs by a number of mechanisms, including over-expression of EGFR [126-128] or its ligands [27,117,121], defective ligand processing [129], activating mutations in EGFR [130,131], or excessive EGFR transactivation [132-136].

There has been a large body of work done relating iRhoms to EGFR ligand shedding and their role in several EGFR related diseases. Autosomal-dominant inherited TOC familial cancer syndrome patients were then found to have an activating mutation in iRhom 2 that increased EGFR ligand shedding, firmly putting iRhom 2 in the midst of EGFR related cancers as well as epithelial homeostasis (Box 1) [57-59]. The syndrome is characterized by palmar and plantar hyperkeratosis, accelerated wound healing, oral leukoplakia, and a markedly elevated risk of developing esophageal squamous cell carcinoma [58,98-103]. In mouse models of the syndrome it was shown that deletion of the EGFR ligand AR or ADAM17 were able to restore normal skin phenotype $[137,138]$ and that the defect was skin specific [139]. While this cancer syndrome is extremely rare it gave us important insights into the iRhom2-EGFR relationship. This relationship in squamous cancers was further cemented when hepatocyte growth factor (HGF) signaling through its receptor MET was found to be dependent on both iRhom1 and 2 regulation of ADAM17 shedding of EGFR ligands [47]. Indeed, iRhom 1 had already been reported to regulate EGFR ligand release and EGFR transactivation in vitro [140]. Recently both iRhoms have been shown to play a role in cervical cancer. Cervical cancer tissue from 83 patients was found to have high expression of both iRhom 1 and 2 compared to normal tissue. High expression was correlated with poor outcome, which the authors relate through in vitro data to EGFR, WNT/ $\beta$-Catenin and TGF $\beta$ signaling [65]. Carcinogenesis however is a process that involves more than one pathway as is evidenced by the mixed results of tyrosine kinase inhibitor clinical trials and increased dual pathway inhibition approaches $[141,142]$. Furthermore, EGFR signaling is involved in much more than 
epithelial cancers alone. As mentioned above, lupus nephritis is dependent on both TNF and EGFR signaling. In a mouse model of lupus nephritis, lack of iRhom 2 resulted in protection from progressive renal injury via these pathways [64].

\subsection{Notch Signaling}

The notch receptor is cleaved by ADAM 10 and 17 . However, cleavage can only occur in the presence of a bound ligand that induces a conformational change in the receptor. Alternatively, mutations in the negative regulatory domain (NRR) of the notch receptor relieve this requirement [143,144]. Once cleaved, the remaining transmembrane and cytoplasmic portions are then processed by $\gamma$-secretase releasing the notch intracellular domain [145], which translocates to the nucleus affecting transcription [146]. The notch pathway is active during development and afterwards. It is responsible for regulating replication, differentiation and the maintenance of stem cells [147]. It has a prominent role in tumorigenesis acting as both a tumor suppressor in squamous cell carcinoma [148], and an oncogene in T-cell leukemia [149]. This is the result of its transcriptional regulation being heavily dependent on the cellular epigenetic context [147]. There are 4 notch receptors in humans (NOTCH1-4). The NOTCH1 NRR is commonly mutated in T-cell leukemias and its ligand-independent cleavage is ADAM17 dependent [143], signifying a potential role for iRhom2 in notch dependent carcinogenesis.

There are currently two studies relating iRhom2 to notch signaling regulation via ADAM17 receptor cleavage. One relates the role of iRhom 2 to hepatocellular carcinoma (HCC) development, specifically in liver cancer stem cells [111]. In 90 human HCC samples the authors found that samples which had increased expression of stem cell markers also had elevated inducible nitric oxide synthase (iNOS), active ADAM17 and notch signaling, all of which were iRhom2 dependent [111]. While increased iNOS activity has been shown to induce ADAM17 activity and be liver protective through cleavage of TNFR1 [84], in this case it was associated with enhanced notch signaling and poor survival [111]. The second paper relates to the spontaneous iRhom 2 uncovered (Uncv) mouse mutation which displays a hairless phenotype in the BALB/c background [112]. In these mice iRhom2 is incapable of supporting ADAM17 maturation which leads to reduced notch receptor processing and reduction in hair shaft cell proliferation and development $[112,113]$.

\subsection{MAVS \& STING}

The innate immune response to non-self molecules (e.g., microbial products), known as pathogen associated molecular patterns (PAMP), induces transcription of pro-inflammatory genes required to control infections and mount an effective adaptive immune response [150]. PAMPs are recognized through various germ-line inherited pattern recognition receptors (PRR) that induce production of pro-inflammatory cytokines [151]. Viral PAMPs include their genome, especially in ways differentiating them from host DNA or RNA [152]. Viral RNA is recognized through the retinoic acid-inducible gene-I (RIG-I) like receptor pathways via mitochondrial antiviral-signaling protein (MAVS, also known as VISA, IPS-1 and Cardif) [153-155], while viral DNA is recognized through the cyclic GMP-AMP synthase (cGAS) via stimulator of interferon genes (STING) pathway [156].

Once RIG-I binds viral RNA, a conformational change has been suggested allowing it to bind to MAVS [155]. However, it was shown without over-expression that RIG-I binds to MAVS even in the absence of a viral infection, although no interferon regulatory transcription factor 3 (IRF-3) recruitment to the complex occurred [157]. Regardless of how the interaction is induced, once the complex is complete, innate immune antiviral responses can ensue via activation of IRF-3 and NF- $\mathrm{KB}$ signaling $[157,158]$. MAVS can be sent off for proteasomal mediated degradation by several E3 ubiquitin ligases including the E3 ligases Ring Finger Protein 5 (RNF5) and membrane-associated ring finger (C3HC4) 5 (MARCH5) $[159,160]$. In the absence of iRhom2, murine innate immunity to Vesicular Stomatitis Virus (VSV) infection was considerably impaired leading to neurological symptoms in all iRhom 2 deficient mice compared to $60 \%$ of wild-type mice. The authors also found that absence of iRhom2 resulted in reduced MAVS levels [10]. Mechanistically, iRhom2 was reported to induce 
auto-ubiquitination of the E3 ligase RNF5 either in the absence of viral infection or during early viral infections (4h). This resulted in proteasomal mediated degradation of RNF5 rescuing MAVS itself from proteasomal mediated degradation. During late infections $(>8 \mathrm{~h})$ iRhom 2 reduced MARCH5 levels saving MAVS again from proteasomal mediated degradation [10].

In response to detecting viral DNA, cGAS produces the second messenger cGAMP, which in turn binds to STING in the ER. STING is then translocated in an iRhom2 dependent manner from the ER to the Golgi and on to the perinuclear microsomes, in a mechanism reminiscent of iRhom-ADAM17 trafficking, albeit mediated by iRhom2's recruitment of the translocon-associated protein (TRAP $\beta$ ) [9]. However, iRhom 2 also stabilizes STING by recruiting a deubiquitylating enzyme that rescues STING from proteasomal mediated degradation. iRhom 2 deficient mice were thus more susceptible to lethal herpes simplex Virus 1 (HSV-1) infections than their wild type counterparts [9]. It further seems that this is a conserved mechanism, as other DNA viruses have evolved mechanisms to evade the innate immune response by disrupting the iRhom2-STING interaction to induce viral latency [114]. Human cytomegalovirus (hCMV) encodes the tegument protein UL82 which is capable of inhibiting the STING-iRhom2-TRAP $\beta$ translocation complex. Moreover, in its absence antiviral gene responses downstream of STING were enhanced [114].

\subsection{K6/16 Balance}

iRhom 2 has a central role in the release of EGFR ligands. An activating mutation of iRhom2, identified in TOC patients, results in palmar and plantar hyperkeratosis, accelerated wound healing, oral leukoplakia, and a markedly elevated risk of developing esophageal squamous cell carcinoma. In addition to iRhom2-induced ADAM17 EGFR ligand processing, iRhom2 can bind directly to the stress-associated keratin K16 playing a pivotal role in the skin characteristics of the syndrome [104]. Keratins are thought to be mostly responsible for skin resilience of the palms and soles as they constitute a vast majority of the proteins expressed in keratinocytes [161-163]. Keratins are expressed in pairs of acidic and basic keratins which heterodimerize. For example, the acidic K16 keratin is paired with the basic K6 keratin [164]. K16 is expressed in palmoplantar epidermis [164], at sites of wound healing [165], associated with squamous cell carcinomas and induced during inflammation [166]. As K16 mutations also present with palmar and plantar hyperkeratosis [167], the authors investigated iRhom 2 gain of function mutations in TOC and their relation to K16 expression. They find in hyperproliferative TOC keratinocytes an enhanced iRhom 2 K16 interaction, in the same binding region used for K6/K16 dimerization. This altered K16 filament organization and reduced expression of its binding partner K6. While in the absence of iRhom2, proliferation and K16 expression are reduced and associated with thinning of the epidermis of the mouse footpad. Changes in $\mathrm{K} 6$ and $\mathrm{K} 16$ expression are found on the transcriptional level [104]. While iRhom2 activity was already linked to squamous cell carcinoma of the esophagus in TOC patients, new evidence further links iRhom 2 expression to oral squamous cell carcinomas [105]. iRhom 2 over-expression was correlated with reduced patient survival and enhanced migration of an oral squamous cell carcinoma line in vitro [105]. In light of the effects of iRhom2 on K6/16 balance in skin keratinocytes as well as its role in EGFR signaling, further investigation is required on iRhom2's role in wound healing and related squamous carcinomas. 
Box 1. iRhom2 in human diseases.

Tylosis with Oesophageal Cancer (TOC) is an autosomal dominant syndrome characterized by palmar and plantar hyperkeratosis, accelerated wound healing, oral leukoplakia, and a markedly elevated risk of developing esophageal squamous cell carcinoma. Using family pedigrees and DNA samples from 3 US, UK and German families, single amino acid substitutions in exon 6 of RHBDF2 were identified as the underlying cause of the syndrome [58]. This was further confirmed independently in a Finnish family [59] and an African family [103] showing again a single amino acid substitution between the two identified before and all within the highly conserved region of the N-terminal cytoplasmic tail of iRhom2: a p.Ile186Thr mutation in the US and UK families, a p.Asp188Asn mutation in the Finnish family, a p.Asp188Tyr in the African family and a p.Pro189Leu mutation in the German family. These mutations lead to an altered distribution of iRhom 2 in skin and dysregulated EGFR signaling [58]. The underlying mechanism was related to the mutations activating iRhom 2 which leads to increased ADAM17 maturation and activity in epidermal keratinocytes from TOC patients, which in turn increases shedding of TNF $\alpha, \mathrm{AR}, \mathrm{TGF} \alpha$ and HB-EGF and enhances EGFR phosphorylation [57]. Consistently, both iRhom 1 and iRhom 2 expression was found to be enhanced in all histological cervical carcinoma types. iRhom1, iRhom 2 and Ki-67 expression were found to correlate with increased tumor stage, invasion and poor clinical outcome [65]. Furthermore, oral squamous cell carcinoma patient samples have been shown to over-express iRhom2, which was found to correlate with poor patient survival but no other clinico-pathological variables [105]. Moreover, iRhom2 expression was increased in cirrhotic liver samples [52], kidney tissue of Lupus nephritis patients [64], and colon samples from inflammatory bowel disease patients [96].

\section{Discussion \& Outlook}

Taken together, iRhom2 has multiple functions during infections and diseases. iRhom2 was originally linked to ADAM17 maturation and activation and accordingly to functions related to ADAM17. However, its role during DNA and RNA viral defense through MAVS and STING suggests that iRhom 2 might have a central role during innate immune functions. Consistently, iRhom 2 is associated with several pathological conditions such as autoimmunity and cancer. Notably, severe phenotypes observed in ADAM17 deficient mice are not observed in mice deficient for iRhom 2 alone, which might suggest little side effects for a therapy targeting iRhom 2 specifically. Further studies could focus on the role of iRhom 2 in other ADAM17 substrates Moreover, a more thorough characterization of both, iRhom 1 and iRhom 2 in multiple model systems will help to further clarify their specific roles in these and other pathways in health and disease.

Author Contributions: M.A.A.-S. and P.A.L. wrote the manuscript. All authors have read and agreed to the published version of the manuscript.

Funding: This study was supported by supported by the German Research Council (SFB974).

Acknowledgments: The authors acknowledge all scientific contributions to the vast field of ADAM17, TNF, iRhom2, rhomboid proteins and apologize if authors could not be cited due to space issues and focus.

Conflicts of Interest: The authors declare no conflict of interest.

\section{Abbreviations}

$\begin{array}{ll}\text { ADAM } & \text { a disintegrin and metalloprotease } \\ \text { AR } & \text { Amphiregulin } \\ \text { cGAS } & \text { cyclic GMP-AMP synthase } \\ \text { cIAP1/2 } & \text { cellular inhibitors of apoptosis 1 and 2 } \\ \text { EGF } & \text { epidermal growth factor } \\ \text { EGFR } & \text { Epidermal growth factor receptor } \\ \text { EPR } & \text { Epiregulin } \\ \text { ERAD } & \text { ER associated ligand degradation } \\ \text { ERK } & \text { extracellular signal-regulated kinases } \\ \text { FERM } & \text { four-point-one, ezrin, radixin, moesin } \\ \text { FRMD8 } & \text { four-point-one, ezrin, radixin, moesin domain-containing protein } 8 \\ \text { HB-EGF } & \text { heparin-binding-EGF-like growth factor } \\ \text { hCMV } & \text { Human cytomegalovirus }\end{array}$




$\begin{array}{ll}\text { HGF } & \text { hepatocyte growth factor } \\ \text { HSV-1 } & \text { herpes simplex Virus 1 } \\ \text { IL-6R } & \text { IL-6 receptor } \\ \text { iNOS } & \text { inducible nitric oxide synthase } \\ \text { IRF-3 } & \text { interferon regulatory transcription factor 3 } \\ \text { iRhom } & \text { inactive Rhomboid } \\ \text { iTAP } & \text { iRhom Tail-Associated Protein } \\ \text { LPS } & \text { Lipopolysaccharides } \\ \text { LUBAC } & \text { linear ubiquitin chain assembly complex } \\ \text { MAD } & \text { mitochondria associated degradation } \\ \text { MAPK } & \text { mitogen activated protein kinases } \\ \text { MARCH5 } & \text { membrane-associated ring finger (C3HC4) } 5 \\ \text { MAVS } & \text { mitochondrial antiviral-signaling protein } \\ \text { NRR } & \text { negative regulatory domain } \\ \text { PAMP } & \text { pathogen associated molecular patterns } \\ \text { PKC } & \text { protein kinase C } \\ \text { PRR } & \text { pattern recognition receptors } \\ \text { PS } & \text { phosphatidyl serine } \\ \text { RIG-I } & \text { retinoic acid-inducible gene-I } \\ \text { RIPK1 } & \text { receptor-interacting serine/threonine-protein kinase 1 } \\ \text { RNF5 } & \text { Ring Finger Protein 5 } \\ \text { sin } & \text { sincere } \\ \text { STING } & \text { stimulator of interferon genes } \\ \text { TACE } & \text { tumor necrosis factor alpha converting enzyme } \\ \text { TGF } \alpha & \text { transforming growth factor alpha } \\ \text { TIMP3 } & \text { tissue inhibitor of metalloprotease 3 } \\ \text { TNFR } & \text { TNF } \alpha \text { receptor } \\ \text { TNF } \alpha & \text { tumor necrosis factor alpha } \\ \text { TOC } & \text { Tylosis with oesophageal cancer } \\ \text { TRADD } & \text { TNFR1-associated death domain } \\ \text { TRAF-2 } & \text { TNFR-associated factor 2 } \\ \text { TRAP } 3 & \text { translocon-associated protein } \\ \text { Tregs } & \text { regulatory T cells } \\ \text { Uncv } & \text { Uncovered } \\ & \end{array}$

\section{References}

1. Dusterhoft, S.; Kunzel, U.; Freeman, M. Rhomboid proteases in human disease: Mechanisms and future prospects. Biochim. Biophys. Acta Mol. Cell Res. 2017, 1864, 2200-2209. [CrossRef]

2. Mayer, U.; Nusslein-Volhard, C. A group of genes required for pattern formation in the ventral ectoderm of the Drosophila embryo. Genes Dev. 1988, 2, 1496-1511. [CrossRef] [PubMed]

3. Sturtevant, M.A.; Roark, M.; Bier, E. The Drosophila rhomboid gene mediates the localized formation of wing veins and interacts genetically with components of the EGF-R signaling pathway. Genes Dev. 1993, 7, 961-973. [CrossRef] [PubMed]

4. Freeman, M. The spitz gene is required for photoreceptor determination in the Drosophila eye where it interacts with the EGF receptor. Mech. Dev. 1994, 48, 25-33. [CrossRef]

5. Urban, S.; Lee, J.R.; Freeman, M. Drosophila rhomboid-1 defines a family of putative intramembrane serine proteases. Cell 2001, 107, 173-182. [CrossRef]

6. Lemberg, M.K.; Freeman, M. Functional and evolutionary implications of enhanced genomic analysis of rhomboid intramembrane proteases. Genome Res. 2007, 17, 1634-1646. [CrossRef]

7. Freeman, M. Rhomboids, signalling and cell biology. Biochem. Soc. Trans. 2016, 44, 945-950. [CrossRef] [PubMed]

8. Zettl, M.; Adrain, C.; Strisovsky, K.; Lastun, V.; Freeman, M. Rhomboid family pseudoproteases use the ER quality control machinery to regulate intercellular signaling. Cell 2011, 145, 79-91. [CrossRef] 
9. Luo, W.W.; Li, S.; Li, C.; Lian, H.; Yang, Q.; Zhong, B.; Shu, H.B. iRhom2 is essential for innate immunity to DNA viruses by mediating trafficking and stability of the adaptor STING. Nat. Immunol. 2016, 17, 1057-1066. [CrossRef]

10. Luo, W.W.; Li, S.; Li, C.; Zheng, Z.Q.; Cao, P.; Tong, Z.; Lian, H.; Wang, S.Y.; Shu, H.B.; Wang, Y.Y. iRhom2 is essential for innate immunity to RNA virus by antagonizing ER- and mitochondria-associated degradation of VISA. PLoS Pathog. 2017, 13, e1006693. [CrossRef]

11. Ticha, A.; Collis, B.; Strisovsky, K. The rhomboid superfamily: Structural mechanisms and chemical biology opportunities. Trends Biochem. Sci. 2018, 43, 726-739. [CrossRef] [PubMed]

12. Dusterhoft, S.; Babendreyer, A.; Giese, A.A.; Flasshove, C.; Ludwig, A. Status update on iRhom and ADAM17: It's still complicated. Biochim. Biophys. Acta Mol. Cell Res. 2019, 1866, 1567-1583. [CrossRef] [PubMed]

13. Dulloo, I.; Muliyil, S.; Freeman, M. The molecular, cellular and pathophysiological roles of iRhom pseudoproteases. Open Biol. 2019, 9, 190003. [CrossRef] [PubMed]

14. Geesala, R.; Issuree, P.D.; Maretzky, T. Novel functions of inactive rhomboid proteins in immunity and disease. J. Leukoc. Biol. 2019, 106, 823-835. [CrossRef]

15. Black, R.A.; Rauch, C.T.; Kozlosky, C.J.; Peschon, J.J.; Slack, J.L.; Wolfson, M.F.; Castner, B.J.; Stocking, K.L.; Reddy, P.; Srinivasan, S.; et al. A metalloproteinase disintegrin that releases tumour-necrosis factor- $\alpha$ from cells. Nature 1997, 385, 729-733. [CrossRef]

16. Moss, M.L.; Jin, S.L.C.; Milla, M.E.; Burkhart, W.; Carter, H.L.; Chen, W.-J.; Clay, W.C.; Didsbury, J.R.; Hassler, D.; Hoffman, C.R.; et al. Cloning of a disintegrin metalloproteinase that processes precursor tumour-necrosis factor- $\alpha$. Nature 1997, 385, 733-736. [CrossRef]

17. Edwards, D.R.; Handsley, M.M.; Pennington, C.J. The ADAM metalloproteinases. Mol. Asp. Med. 2008, 29, 258-289. [CrossRef] [PubMed]

18. Peschon, J.J.; Slack, J.L.; Reddy, P.; Stocking, K.L.; Sunnarborg, S.W.; Lee, D.C.; Russell, W.E.; Castner, B.J.; Johnson, R.S.; Fitzner, J.N.; et al. An essential role for ectodomain shedding in mammalian development. Science 1998, 282, 1281-1284. [CrossRef]

19. Arribas, J.; Coodly, L.; Vollmer, P.; Kishimoto, T.K.; Rose-John, S.; Massague, J. Diverse cell surface protein ectodomains are shed by a system sensitive to metalloprotease inhibitors. J. Biol. Chem. 1996, 271, 11376-11382. [CrossRef]

20. Zunke, F.; Rose-John, S. The shedding protease ADAM17: Physiology and pathophysiology. Biochim. Biophys. Acta Mol. Cell Res. 2017, 1864, 2059-2070. [CrossRef]

21. Schlondorff, J.; Becherer, J.D.; Blobel, C.P. Intracellular maturation and localization of the tumour necrosis factor alpha convertase (TACE). Biochem. J. 2000, 347, 131-138. [CrossRef] [PubMed]

22. Endres, K.; Anders, A.; Kojro, E.; Gilbert, S.; Fahrenholz, F.; Postina, R. Tumor necrosis factor-alpha converting enzyme is processed by proprotein-convertases to its mature form which is degraded upon phorbol ester stimulation. Eur. J. Biochem. 2003, 270, 2386-2393. [CrossRef] [PubMed]

23. Wong, E.; Maretzky, T.; Peleg, Y.; Blobel, C.P.; Sagi, I. The functional maturation of a disintegrin and metalloproteinase (ADAM) 9, 10, and 17 requires processing at a newly identified proprotein convertase (PC) cleavage site. J. Biol. Chem. 2015, 290, 12135-12146. [CrossRef] [PubMed]

24. Fan, H.; Derynck, R. Ectodomain shedding of TGF-alpha and other transmembrane proteins is induced by receptor tyrosine kinase activation and MAP kinase signaling cascades. EMBO J. 1999, 18, 6962-6972. [CrossRef] [PubMed]

25. Gechtman, Z.; Alonso, J.L.; Raab, G.; Ingber, D.E.; Klagsbrun, M. The shedding of membrane-anchored heparin-binding epidermal-like growth factor is regulated by the Raf/mitogen-activated protein kinase cascade and by cell adhesion and spreading. J. Biol. Chem. 1999, 274, 28828-28835. [CrossRef]

26. Fan, H.; Turck, C.W.; Derynck, R. Characterization of growth factor-induced serine phosphorylation of tumor necrosis factor-alpha converting enzyme and of an alternatively translated polypeptide. J. Biol. Chem. 2003, 278, 18617-18627. [CrossRef]

27. Xu, P.; Derynck, R. Direct activation of TACE-mediated ectodomain shedding by p38 MAP kinase regulates EGF receptor-dependent cell proliferation. Mol. Cell 2010, 37, 551-566. [CrossRef]

28. Killock, D.J.; Ivetic, A. The cytoplasmic domains of TNFalpha-converting enzyme (TACE/ADAM17) and L-selectin are regulated differently by $\mathrm{p} 38 \mathrm{MAPK}$ and PKC to promote ectodomain shedding. Biochem. J. 2010, 428, 293-304. [CrossRef] 
29. Lemjabbar-Alaoui, H.; Sidhu, S.S.; Mengistab, A.; Gallup, M.; Basbaum, C. TACE/ADAM-17 phosphorylation by PKC-epsilon mediates premalignant changes in tobacco smoke-exposed lung cells. PLoS ONE 2011, 6, e17489. [CrossRef]

30. Schwarz, J.; Schmidt, S.; Will, O.; Koudelka, T.; Kohler, K.; Boss, M.; Rabe, B.; Tholey, A.; Scheller, J.; Schmidt-Arras, D.; et al. Polo-like kinase 2, a novel ADAM17 signaling component, regulates tumor necrosis factor alpha ectodomain shedding. J. Biol. Chem. 2014, 289, 3080-3093. [CrossRef]

31. Saad, M.I.; Alhayyani, S.; McLeod, L.; Yu, L.; Alanazi, M.; Deswaerte, V.; Tang, K.; Jarde, T.; Smith, J.A.; Prodanovic, Z.; et al. ADAM17 selectively activates the IL-6 trans-signaling/ERK MAPK axis in KRAS-addicted lung cancer. EMBO Mol. Med. 2019, 11, 4. [CrossRef] [PubMed]

32. Soond, S.M.; Everson, B.; Riches, D.W.; Murphy, G. ERK-mediated phosphorylation of Thr735 in TNFalpha-converting enzyme and its potential role in TACE protein trafficking. J. Cell Sci. 2005, 118, 2371-2380. [CrossRef]

33. Reddy, P.; Slack, J.L.; Davis, R.; Cerretti, D.P.; Kozlosky, C.J.; Blanton, R.A.; Shows, D.; Peschon, J.J.; Black, R.A. Functional analysis of the domain structure of tumor necrosis factor-alpha converting enzyme. J. Biol. Chem. 2000, 275, 14608-14614. [CrossRef] [PubMed]

34. Le Gall, S.M.; Maretzky, T.; Issuree, P.D.; Niu, X.D.; Reiss, K.; Saftig, P.; Khokha, R.; Lundell, D.; Blobel, C.P. ADAM17 is regulated by a rapid and reversible mechanism that controls access to its catalytic site. J. Cell Sci. 2010, 123, 3913-3922. [CrossRef] [PubMed]

35. Xu, P.; Liu, J.; Sakaki-Yumoto, M.; Derynck, R. TACE activation by MAPK-mediated regulation of cell surface dimerization and TIMP3 association. Sci. Signal. 2012, 5, ra34. [CrossRef]

36. Wisniewska, M.; Goettig, P.; Maskos, K.; Belouski, E.; Winters, D.; Hecht, R.; Black, R.; Bode, W. Structural determinants of the ADAM inhibition by TIMP-3: Crystal structure of the TACE-N-TIMP-3 complex. J. Mol. Biol. 2008, 381, 1307-1319. [CrossRef]

37. Parra, L.M.; Hartmann, M.; Schubach, S.; Li, Y.; Herrlich, P.; Herrlich, A. Distinct intracellular domain substrate modifications selectively regulate ectodomain cleavage of NRG1 or CD44. Mol. Cell Biol. 2015, 35, 3381-3395. [CrossRef]

38. Willems, S.H.; Tape, C.J.; Stanley, P.L.; Taylor, N.A.; Mills, I.G.; Neal, D.E.; McCafferty, J.; Murphy, G. Thiol isomerases negatively regulate the cellular shedding activity of ADAM17. Biochem. J. 2010, 428, 439-450. [CrossRef]

39. Dusterhoft, S.; Jung, S.; Hung, C.W.; Tholey, A.; Sonnichsen, F.D.; Grotzinger, J.; Lorenzen, I. Membrane-proximal domain of a disintegrin and metalloprotease-17 represents the putative molecular switch of its shedding activity operated by protein-disulfide isomerase. J. Am. Chem Soc. 2013, 135, 5776-5781. [CrossRef]

40. Dusterhoft, S.; Hobel, K.; Oldefest, M.; Lokau, J.; Waetzig, G.H.; Chalaris, A.; Garbers, C.; Scheller, J.; Rose-John, S.; Lorenzen, I.; et al. A disintegrin and metalloprotease 17 dynamic interaction sequence, the sweet tooth for the human interleukin 6 receptor. J. Biol. Chem. 2014, 289, 16336-16348. [CrossRef]

41. Bennett, T.A.; Edwards, B.S.; Sklar, L.A.; Rogelj, S. Sulfhydryl regulation of L-selectin shedding: Phenylarsine oxide promotes activation-independent L-selectin shedding from leukocytes. J. Immunol. 2000, 164, 4120-4129. [CrossRef] [PubMed]

42. Wang, Y.; Herrera, A.H.; Li, Y.; Belani, K.K.; Walcheck, B. Regulation of mature ADAM17 by redox agents for L-selectin shedding. J. Immunol. 2009, 182, 2449-2457. [CrossRef] [PubMed]

43. Adrain, C.; Zettl, M.; Christova, Y.; Taylor, N.; Freeman, M. Tumor necrosis factor signaling requires iRhom2 to promote trafficking and activation of TACE. Science 2012, 335, 225-228. [CrossRef] [PubMed]

44. McIlwain, D.R.; Lang, P.A.; Maretzky, T.; Hamada, K.; Ohishi, K.; Maney, S.K.; Berger, T.; Murthy, A.; Duncan, G.; Xu, H.C.; et al. iRhom2 regulation of TACE controls TNF-mediated protection against Listeria and responses to LPS. Science 2012, 335, 229-232. [CrossRef]

45. Maretzky, T.; Mcllwain, D.R.; Issuree, P.D.; Li, X.; Malapeira, J.; Amin, S.; Lang, P.A.; Mak, T.W.; Blobel, C.P. iRhom 2 controls the substrate selectivity of stimulated ADAM17-dependent ectodomain shedding. Proc. Natl. Acad. Sci. USA 2013, 110, 11433-11438. [CrossRef]

46. Tang, B.; Li, X.; Maretzky, T.; Perez-Aguilar, J.M.; McIlwain, D.; Xie, Y.; Zheng, Y.; Mak, T.W.; Weinstein, H.; Blobel, C.P. Substrate-selective protein ectodomain shedding by ADAM17 and iRhom2 depends on their juxtamembrane and transmembrane domains. FASEB J. 2020, 34, 4956-4969. [CrossRef] 
47. Cataisson, C.; Michalowski, A.M.; Shibuya, K.; Ryscavage, A.; Klosterman, M.; Wright, L.; Dubois, W.; Liu, F.; Zhuang, A.; Rodrigues, K.B.; et al. MET signaling in keratinocytes activates EGFR and initiates squamous carcinogenesis. Sci. Signal. 2016, 9, ra62. [CrossRef]

48. Li, X.; Maretzky, T.; Weskamp, G.; Monette, S.; Qing, X.; Issuree, P.D.; Crawford, H.C.; McIlwain, D.R.; Mak, T.W.; Salmon, J.E.; et al. iRhoms 1 and 2 are essential upstream regulators of ADAM17-dependent EGFR signaling. Proc. Natl. Acad. Sci. USA 2015, 112, 6080-6085. [CrossRef]

49. Christova, Y.; Adrain, C.; Bambrough, P.; Ibrahim, A.; Freeman, M. Mammalian iRhoms have distinct physiological functions including an essential role in TACE regulation. EMBO Rep. 2013, 14, 884-890. [CrossRef]

50. Weskamp, G.; Tushaus, J.; Li, D.; Feederle, R.; Maretzky, T.; Swendemann, S.; Falck-Pedersen, E.; McIlwain, D.R.; Mak, T.W.; Salmon, J.E.; et al. ADAM17 stabilizes its interacting partner inactive Rhomboid 2 (iRhom2) but not inactive Rhomboid 1 (iRhom1). J. Biol. Chem. 2020, 295, 4350-4358. [CrossRef]

51. Arcidiacono, P.; Webb, C.M.; Brooke, M.A.; Zhou, H.; Delaney, P.J.; Ng, K.E.; Blaydon, D.C.; Tinker, A.; Kelsell, D.P.; Chikh, A. p63 is a key regulator of iRHOM2 signalling in the keratinocyte stress response. Nat. Commun. 2018, 9, 1021. [CrossRef]

52. Sundaram, B.; Behnke, K.; Belancic, A.; Al-Salihi, M.A.; Thabet, Y.; Polz, R.; Pellegrino, R.; Zhuang, Y.; Shinde, P.V.; Xu, H.C.; et al. iRhom2 inhibits bile duct obstruction-induced liver fibrosis. Sci. Signal. 2019, 12, eaax1194. [CrossRef]

53. Hosur, V.; Johnson, K.R.; Burzenski, L.M.; Stearns, T.M.; Maser, R.S.; Shultz, L.D. Rhbdf2 mutations increase its protein stability and drive EGFR hyperactivation through enhanced secretion of amphiregulin. Proc. Natl. Acad. Sci. USA 2014, 111, E2200-E2209. [CrossRef]

54. Siggs, O.M.; Xiao, N.; Wang, Y.; Shi, H.; Tomisato, W.; Li, X.; Xia, Y.; Beutler, B. iRhom2 is required for the secretion of mouse TNFalpha. Blood 2012, 119, 5769-5771. [CrossRef] [PubMed]

55. Li, X.; Maretzky, T.; Perez-Aguilar, J.M.; Monette, S.; Weskamp, G.; Le Gall, S.; Beutler, B.; Weinstein, H.; Blobel, C.P. Structural modeling defines transmembrane residues in ADAM17 that are crucial for Rhbdf2-ADAM17-dependent proteolysis. J. Cell Sci. 2017, 130, 868-878. [CrossRef] [PubMed]

56. Siggs, O.M.; Grieve, A.; Xu, H.; Bambrough, P.; Christova, Y.; Freeman, M. Genetic interaction implicates iRhom2 in the regulation of EGF receptor signalling in mice. Biol. Open 2014, 3, 1151-1157. [CrossRef] [PubMed]

57. Brooke, M.A.; Etheridge, S.L.; Kaplan, N.; Simpson, C.; O’Toole, E.A.; Ishida-Yamamoto, A.; Marches, O.; Getsios, S.; Kelsell, D.P. iRHOM2-dependent regulation of ADAM17 in cutaneous disease and epidermal barrier function. Hum. Mol. Genet. 2014, 23, 4064-4076. [CrossRef]

58. Blaydon, D.C.; Etheridge, S.L.; Risk, J.M.; Hennies, H.C.; Gay, L.J.; Carroll, R.; Plagnol, V.; McRonald, F.E.; Stevens, H.P.; Spurr, N.K.; et al. RHBDF2 mutations are associated with tylosis, a familial esophageal cancer syndrome. Am. J. Hum. Genet. 2012, 90, 340-346. [CrossRef] [PubMed]

59. Saarinen, S.; Vahteristo, P.; Lehtonen, R.; Aittomaki, K.; Launonen, V.; Kiviluoto, T.; Aaltonen, L.A. Analysis of a Finnish family confirms RHBDF2 mutations as the underlying factor in tylosis with esophageal cancer. Fam. Cancer 2012, 11, 525-528. [CrossRef] [PubMed]

60. Maney, S.K.; Mcllwain, D.R.; Polz, R.; Pandyra, A.A.; Sundaram, B.; Wolff, D.; Ohishi, K.; Maretzky, T.; Brooke, M.A.; Evers, A.; et al. Deletions in the cytoplasmic domain of iRhom1 and iRhom2 promote shedding of the TNF receptor by the protease ADAM17. Sci. Signal. 2015, 8, ra109. [CrossRef]

61. Issuree, P.D.; Maretzky, T.; Mcllwain, D.R.; Monette, S.; Qing, X.; Lang, P.A.; Swendeman, S.L.; Park-Min, K.H.; Binder, N.; Kalliolias, G.D.; et al. iRHOM2 is a critical pathogenic mediator of inflammatory arthritis. J. Clin. Investig. 2013, 123, 928-932. [CrossRef]

62. Green, L.A.; Njoku, V.; Mund, J.; Case, J.; Yoder, M.; Murphy, M.P.; Clauss, M. Endogenous transmembrane TNF-alpha protects against premature senescence in endothelial colony forming cells. Circ. Res. 2016, 118, 1512-1524. [CrossRef]

63. Urriola-Munoz, P.; Li, X.; Maretzky, T.; McIlwain, D.R.; Mak, T.W.; Reyes, J.G.; Blobel, C.P.; Moreno, R.D. The xenoestrogens biphenol-A and nonylphenol differentially regulate metalloprotease-mediated shedding of EGFR ligands. J. Cell Physiol. 2018, 233, 2247-2256. [CrossRef]

64. Qing, X.; Chinenov, Y.; Redecha, P.; Madaio, M.; Roelofs, J.J.; Farber, G.; Issuree, P.D.; Donlin, L.; McLlwain, D.R.; Mak, T.W.; et al. iRhom2 promotes lupus nephritis through TNF-alpha and EGFR signaling. J. Clin. Investig. 2018, 128, 1397-1412. [CrossRef] [PubMed] 
65. Xu, Q.; Chen, C.; Liu, B.; Lin, Y.; Zheng, P.; Zhou, D.; Xie, Y.; Lin, Y.; Guo, C.; Liu, J.; et al. Association of iRhom1 and iRhom 2 expression with prognosis in patients with cervical cancer and possible signaling pathways. Oncol. Rep. 2020, 43, 41-54. [CrossRef] [PubMed]

66. Grieve, A.G.; Xu, H.; Kunzel, U.; Bambrough, P.; Sieber, B.; Freeman, M. Phosphorylation of iRhom2 at the plasma membrane controls mammalian TACE-dependent inflammatory and growth factor signalling. eLife 2017, 6, e23968. [CrossRef]

67. Cavadas, M.; Oikonomidi, I.; Gaspar, C.J.; Burbridge, E.; Badenes, M.; Felix, I.; Bolado, A.; Hu, T.; Bileck, A.; Gerner, C.; et al. Phosphorylation of iRhom 2 controls stimulated proteolytic shedding by the metalloprotease ADAM17/TACE. Cell Rep. 2017, 21, 745-757. [CrossRef] [PubMed]

68. Kunzel, U.; Grieve, A.G.; Meng, Y.; Sieber, B.; Cowley, S.A.; Freeman, M. FRMD8 promotes inflammatory and growth factor signalling by stabilising the iRhom/ADAM17 sheddase complex. eLife 2018, 7, e35012. [CrossRef]

69. Oikonomidi, I.; Burbridge, E.; Cavadas, M.; Sullivan, G.; Collis, B.; Naegele, H.; Clancy, D.; Brezinova, J.; $\mathrm{Hu}, \mathrm{T}$; Bileck, A.; et al. iTAP, a novel iRhom interactor, controls TNF secretion by policing the stability of iRhom/TACE. eLife 2018, 7, e35032. [CrossRef]

70. Miettinen, P.J.; Berger, J.E.; Meneses, J.; Phung, Y.; Pedersen, R.A.; Werb, Z.; Derynck, R. Epithelial immaturity and multiorgan failure in mice lacking epidermal growth factor receptor. Nature 1995, 376, 337-341. [CrossRef] [PubMed]

71. Lichtenthaler, S.F.; O'Hara, B.F.; Blobel, C.P. iRhoms in the brain-A new frontier? Cell Cycle 2015, 14, 3003-3004. [CrossRef] [PubMed]

72. Lord, J.; Cruchaga, C. The epigenetic landscape of Alzheimer's disease. Nat. Neurosci. 2014, 17, 1138-1140. [CrossRef] [PubMed]

73. De Jager, P.L.; Srivastava, G.; Lunnon, K.; Burgess, J.; Schalkwyk, L.C.; Yu, L.; Eaton, M.L.; Keenan, B.T.; Ernst, J.; McCabe, C.; et al. Alzheimer's disease: Early alterations in brain DNA methylation at ANK1, BIN1, RHBDF2 and other loci. Nat. Neurosci. 2014, 17, 1156-1163. [CrossRef] [PubMed]

74. Dostert, C.; Grusdat, M.; Letellier, E.; Brenner, D. The TNF family of ligands and receptors: Communication Modules in the immune system and beyond. Physiol. Rev. 2019, 99, 115-160. [CrossRef]

75. Kondylis, V.; Pasparakis, M. RIP kinases in liver cell death, inflammation and cancer. Trends Mol. Med. 2019, 25, 47-63. [CrossRef]

76. Hsu, H.; Huang, J.; Shu, H.B.; Baichwal, V.; Goeddel, D.V. TNF-dependent recruitment of the protein kinase RIP to the TNF receptor-1 signaling complex. Immunity 1996, 4, 387-396. [CrossRef]

77. Ting, A.T.; Pimentel-Muinos, F.X.; Seed, B. RIP mediates tumor necrosis factor receptor 1 activation of NF-kappaB but not Fas/APO-1-initiated apoptosis. EMBO J. 1996, 15, 6189-6196. [CrossRef]

78. Hsu, H.; Xiong, J.; Goeddel, D.V. The TNF receptor 1-associated protein TRADD signals cell death and NF-kappa B activation. Cell 1995, 81, 495-504. [CrossRef]

79. Xu, D.; Jin, T.; Zhu, H.; Chen, H.; Ofengeim, D.; Zou, C.; Mifflin, L.; Pan, L.; Amin, P.; Li, W.; et al. TBK1 suppresses RIPK1-driven apoptosis and inflammation during development and in aging. Cell 2018, 174, 1477-1491. [CrossRef]

80. Feoktistova, M.; Geserick, P.; Kellert, B.; Dimitrova, D.P.; Langlais, C.; Hupe, M.; Cain, K.; MacFarlane, M.; Hacker, G.; Leverkus, M. cIAPs block Ripoptosome formation, a RIP1/caspase-8 containing intracellular cell death complex differentially regulated by cFLIP isoforms. Mol. Cell 2011, 43, 449-463. [CrossRef]

81. Cai, Z.; Jitkaew, S.; Zhao, J.; Chiang, H.C.; Choksi, S.; Liu, J.; Ward, Y.; Wu, L.G.; Liu, Z.G. Plasma membrane translocation of trimerized MLKL protein is required for TNF-induced necroptosis. Nat. Cell Biol. 2014, 16, 55-65. [CrossRef] [PubMed]

82. Faustman, D.; Davis, M. TNF receptor 2 pathway: Drug target for autoimmune diseases. Nat. Rev. Drug Discov. 2010, 9, 482-493. [CrossRef] [PubMed]

83. Grech, A.P.; Gardam, S.; Chan, T.; Quinn, R.; Gonzales, R.; Basten, A.; Brink, R. Tumor necrosis factor receptor 2 (TNFR2) signaling is negatively regulated by a novel, carboxyl-terminal TNFR-associated factor 2 (TRAF2)-binding site. J. Biol. Chem. 2005, 280, 31572-31581. [CrossRef]

84. Chanthaphavong, R.S.; Loughran, P.A.; Lee, T.Y.; Scott, M.J.; Billiar, T.R. A role for cGMP in inducible nitric-oxide synthase (iNOS)-induced tumor necrosis factor (TNF) alpha-converting enzyme (TACE/ADAM17) activation, translocation, and TNF receptor 1 (TNFR1) shedding in hepatocytes. J. Biol. Chem. 2012, 287, 35887-35898. [CrossRef] 
85. Pfeffer, K.; Matsuyama, T.; Kündig, T.M.; Wakeham, A.; Kishihara, K.; Shahinian, A.; Wiegmann, K.; Ohashi, P.S.; Krönke, M.; Mak, T.W. Mice deficient for the $55 \mathrm{kd}$ tumor necrosis factor receptor are resistant to endotoxic shock, yet succumb to L. monocytogenes infection. Cell 1993, 73, 457-467. [CrossRef]

86. Rothe, J.; Lesslauer, W.; Lötscher, H.; Lang, Y.; Koebel, P.; Köntgen, F.; Althage, A.; Zinkernagel, R.; Steinmetz, M.; Bluethmann, H. Mice lacking the tumour necrosis factor receptor 1 are resistant to IMF-mediated toxicity but highly susceptible to infection by Listeria monocytogenes. Nature 1993, 364, 798-802. [CrossRef]

87. Pasparakis, M.; Alexopoulou, L.; Episkopou, V.; Kollias, G. Immune and inflammatory responses in TNF alpha-deficient mice: A critical requirement for TNF alpha in the formation of primary B cell follicles, follicular dendritic cell networks and germinal centers, and in the maturation of the humoral immune response. J. Exp. Med. 1996, 184, 1397-1411. [CrossRef]

88. Alexopoulou, L.; Kranidioti, K.; Xanthoulea, S.; Denis, M.; Kotanidou, A.; Douni, E.; Blackshear, P.J.; Kontoyiannis, D.L.; Kollias, G. Transmembrane TNF protects mutant mice against intracellular bacterial infections, chronic inflammation and autoimmunity. Eur. J. Immunol. 2006, 36, 2768-2780. [CrossRef]

89. Barnette, D.N.; Cahill, T.J.; Gunadasa-Rohling, M.; Carr, C.A.; Freeman, M.; Riley, P.R. iRhom2-mediated proinflammatory signalling regulates heart repair following myocardial infarction. JCI Insight 2018, 3, e98268. [CrossRef]

90. Chaohui, C.; Wei, H.; Hongfeng, W.; Yueliang, Z.; Xiaoqin, P.; Pingli, Z.; Zhibing, A. iRhom2 promotes atherosclerosis through macrophage inflammation and induction of oxidative stress. Biochem. Biophys. Res. Commun. 2018, 503, 1897-1904. [CrossRef]

91. Satoh, M.; Ishikawa, Y.; Itoh, T.; Minami, Y.; Takahashi, Y.; Nakamura, M. The expression of TNF-alpha converting enzyme at the site of ruptured plaques in patients with acute myocardial infarction. Eur. J. Clin. Investig. 2008, 38, 97-105. [CrossRef]

92. Lee, M.Y.; Kang, J.S.; Go, R.E.; Byun, Y.S.; Wi, Y.J.; Hwang, K.A.; Choi, J.H.; Kim, H.C.; Choi, K.C.; Nam, K.H. Collagen-induced arthritis analysis in Rhbdf2 knockout mouse. Biomol. Ther. 2018, 26, 298-305. [CrossRef]

93. Haxaire, C.; Hakobyan, N.; Pannellini, T.; Carballo, C.; Mcllwain, D.; Mak, T.W.; Rodeo, S.; Acharya, S.; Li, D.; Szymonifka, J.; et al. Blood-induced bone loss in murine hemophilic arthropathy is prevented by blocking the iRhom2/ADAM17/TNF-alpha pathway. Blood 2018, 132, 1064-1074. [CrossRef]

94. Kim, J.H.; Kim, J.; Chun, J.; Lee, C.; Im, J.P.; Kim, J.S. Role of iRhom2 in intestinal ischemia-reperfusionmediated acute lung injury. Sci. Rep. 2018, 8, 1. [CrossRef]

95. Chenxu, G.; Minxuan, X.; Yuting, Q.; Tingting, G.; Jinxiao, L.; Mingxing, W.; Sujun, W.; Yongjie, M.; Deshuai, L.; Qiang, L.; et al. iRhom2 loss alleviates renal injury in long-term PM2.5-exposed mice by suppression of inflammation and oxidative stress. Redox Biol. 2018, 19, 147-157. [CrossRef] [PubMed]

96. Kim, J.H.; Hwang, S.W.; Koh, J.; Chun, J.; Lee, C.; Im, J.P.; Kim, J.S. Inactive rhomboid protein 2 mediates intestinal inflammation by releasing tumor necrosis factor-alpha. Inflamm. Bowel Dis. 2020, 26, 242-253. [CrossRef]

97. Geesala, R.; Schanz, W.; Biggs, M.; Dixit, G.; Skurski, J.; Gurung, P.; Meyerholz, D.K.; Elliott, D.; Issuree, P.D.; Maretzky, T. Loss of RHBDF2 results in an early-onset spontaneous murine colitis. J. Leukoc. Biol. 2019, 105, 767-781. [CrossRef]

98. Ellis, A.; Field, J.K.; Field, E.A.; Friedmann, P.S.; Fryer, A.; Howard, P.; Leigh, I.M.; Risk, J.; Shaw, J.M.; Whittaker, J. Tylosis associated with carcinoma of the oesophagus and oral leukoplakia in a large Liverpool family-A review of six generations. Eur. J. Cancer B Oral. Oncol. 1994, 30B, 102-112. [CrossRef]

99. Hennies, H.C.; Hagedorn, M.; Reis, A. Palmoplantar keratoderma in association with carcinoma of the esophagus maps to chromosome 17q distal to the keratin gene cluster. Genomics 1995, 29, 537-540. [CrossRef] [PubMed]

100. Stevens, H.P.; Kelsell, D.P.; Bryant, S.P.; Bishop, D.T.; Spurr, N.K.; Weissenbach, J.; Marger, D.; Marger, R.S.; Leigh, I.M. Linkage of an American pedigree with palmoplantar keratoderma and malignancy (palmoplantar ectodermal dysplasia type III) to 17q24. Literature survey and proposed updated classification of the keratodermas. Arch. Derm. 1996, 132, 640-651. [CrossRef]

101. Varela, A.B.; Blanco Rodriguez, M.M.; Boullosa, P.E.; Silva, J.G. Tylosis A with squamous cell carcinoma of the oesophagus in a Spanish family. Eur. J. Gastroenterol. Hepatol. 2011, 23, 286-288. [CrossRef] [PubMed] 
102. Hosur, V.; Burzenski, L.M.; Stearns, T.M.; Farley, M.L.; Sundberg, J.P.; Wiles, M.V.; Shultz, L.D. Early induction of NRF2 antioxidant pathway by RHBDF2 mediates rapid cutaneous wound healing. Exp. Mol. Pathol. 2017, 102, 337-346. [CrossRef] [PubMed]

103. Mokoena, T.; Smit, J.G.M.; Karusseit, V.O.; Dorfling, C.M.; van Rensburg, E.J. Tylosis associated with squamous cell carcinoma of the oesophagus (TOC): Report of an African family with a novel RHBDF2 variant. Clin. Genet. 2018, 93, 1114-1116. [CrossRef] [PubMed]

104. Maruthappu, T.; Chikh, A.; Fell, B.; Delaney, P.J.; Brooke, M.A.; Levet, C.; Moncada-Pazos, A.; Ishida-Yamamoto, A.; Blaydon, D.; Waseem, A.; et al. Rhomboid family member 2 regulates cytoskeletal stress-associated Keratin 16. Nat. Commun. 2017, 8, 14174. [CrossRef] [PubMed]

105. Agwae, M.E.; Shaw, R.J.; Triantafyllou, A.; Greaney, F.S.T.; Ben Salah, K.; Risk, J.M. iRhom2 in the pathogenesis of oral squamous cell carcinoma. Mol. Biol. Rep. 2020, 47, 3987-3992. [CrossRef]

106. Joedicke, J.J.; Myers, L.; Carmody, A.B.; Messer, R.J.; Wajant, H.; Lang, K.S.; Lang, P.A.; Mak, T.W.; Hasenkrug, K.J.; Dittmer, U. Activated CD8+ T cells induce expansion of Vbeta5+ regulatory T cells via TNFR2 signaling. J. Immunol. 2014, 193, 2952-2960. [CrossRef] [PubMed]

107. Grinberg-Bleyer, Y.; Saadoun, D.; Baeyens, A.; Billiard, F.; Goldstein, J.D.; Gregoire, S.; Martin, G.H.; Elhage, R.; Derian, N.; Carpentier, W.; et al. Pathogenic T cells have a paradoxical protective effect in murine autoimmune diabetes by boosting Tregs. J. Clin. Investig. 2010, 120, 4558-4568. [CrossRef]

108. Kleijwegt, F.S.; Laban, S.; Duinkerken, G.; Joosten, A.M.; Zaldumbide, A.; Nikolic, T.; Roep, B.O. Critical role for TNF in the induction of human antigen-specific regulatory $\mathrm{T}$ cells by tolerogenic dendritic cells. J. Immunol. 2010, 185, 1412-1418. [CrossRef]

109. Chen, X.; Baumel, M.; Mannel, D.N.; Howard, O.M.; Oppenheim, J.J. Interaction of TNF with TNF receptor type 2 promotes expansion and function of mouse CD4+CD25+ T regulatory cells. J. Immunol. 2007, 179, 154-161. [CrossRef]

110. Mohler, K.M.; Torrance, D.S.; Smith, C.A.; Goodwin, R.G.; Stremler, K.E.; Fung, V.P.; Madani, H.; Widmer, M.B. Soluble tumor necrosis factor (TNF) receptors are effective therapeutic agents in lethal endotoxemia and function simultaneously as both TNF carriers and TNF antagonists. J. Immunol. 1993, 151, 1548.

111. Wang, R.; Li, Y.; Tsung, A.; Huang, H.; Du, Q.; Yang, M.; Deng, M.; Xiong, S.; Wang, X.; Zhang, L.; et al. iNOS promotes CD24(+)CD133(+) liver cancer stem cell phenotype through a TACE/ADAM17-dependent Notch signaling pathway. Proc. Natl. Acad. Sci. USA 2018, 115, E10127-E10136. [CrossRef] [PubMed]

112. Leilei, Y.; Bing, L.; Yang, L.; Shaoxia, W.; Yuan, X.; Dongping, W.; Huahu, Y.; Shichen, S.; Guangzhou, Z.; Ruiyun, P.; et al. iRhom 2 mutation leads to aberrant hair follicle differentiation in mice. PLOS ONE 2014, 9, e115114. [CrossRef] [PubMed]

113. Yang, L.; Li, W.; Liu, B.; Wang, S.; Zeng, L.; Zhang, C.; Li, Y. iRhom2 (Uncv) mutation blocks bulge stem cells assuming the fate of hair follicle. Arch. Derm. Res. 2016, 308, 503-510. [CrossRef]

114. Fu, Y.Z.; Su, S.; Gao, Y.Q.; Wang, P.P.; Huang, Z.F.; Hu, M.M.; Luo, W.W.; Li, S.; Luo, M.H.; Wang, Y.Y.; et al. Human cytomegalovirus tegument protein UL82 inhibits STING-mediated signaling to evade antiviral immunity. Cell Host Microbe 2017, 21, 231-243. [CrossRef]

115. Sigismund, S.; Avanzato, D.; Lanzetti, L. Emerging functions of the EGFR in cancer. Mol. Oncol. 2018, 12, 3-20. [CrossRef]

116. Al-Salihi, M.A.; Ulmer, S.C.; Doan, T.; Nelson, C.D.; Crotty, T.; Prescott, S.M.; Stafforini, D.M.; Topham, M.K. Cyclooxygenase- 2 transactivates the epidermal growth factor receptor through specific E-prostanoid receptors and tumor necrosis factor-alpha converting enzyme. Cell Signal. 2007, 19, 1956-1963. [CrossRef]

117. Picihard, V.; Berthois, Y.; Roccabianca, M.; Prevot, C.; Sarrazin, M.; Portugal, H.; Kumar, S.; Kumar, P.; Rognoni, J.B. Concomitant cell growth and differentiation are dependent on erbB1 and integrin activation in an autonomously surviving colon adenocarcinoma: Involvement of autocrine amphiregulin secretion. Anticancer Res. 2006, 26, 2769-2783.

118. Phung, T.L.; Ziv, K.; Dabydeen, D.; Eyiah-Mensah, G.; Riveros, M.; Perruzzi, C.; Sun, J.; Monahan-Earley, R.A.; Shiojima, I.; Nagy, J.A.; et al. Pathological angiogenesis is induced by sustained Akt signaling and inhibited by rapamycin. Cancer Cell 2006, 10, 159-170. [CrossRef]

119. Sahin, U.; Weskamp, G.; Kelly, K.; Zhou, H.M.; Higashiyama, S.; Peschon, J.; Hartmann, D.; Saftig, P.; Blobel, C.P. Distinct roles for ADAM10 and ADAM17 in ectodomain shedding of six EGFR ligands. J. Cell Biol. 2004, 164, 769-779. [CrossRef] 
120. Sahin, U.; Blobel, C.P. Ectodomain shedding of the EGF-receptor ligand epigen is mediated by ADAM17. FEBS Lett 2007, 581, 41-44. [CrossRef]

121. Nickell, K.A.; Halper, J.; Moses, H.L. Transforming growth factors in solid human malignant neoplasms. Cancer Res. 1983, 43, 1966. [PubMed]

122. Hendler, F.J.; Ozanne, B.W. Human squamous cell lung cancers express increased epidermal growth factor receptors. J. Clin. Investig. 1984, 74, 647-651. [CrossRef] [PubMed]

123. Porebska, I.; Harlozinska, A.; Bojarowski, T. Expression of the tyrosine kinase activity growth factor receptors (EGFR, ERB B2, ERB B3) in colorectal adenocarcinomas and adenomas. Tumour Biol. 2000, 21, 105-115. [CrossRef]

124. Layfield, L.J.; Bernard, P.S.; Goldstein, N.S. Color multiplex polymerase chain reaction for quantitative analysis of epidermal growth factor receptor genes in colorectal adenocarcinoma. J. Surg. Oncol. 2003, 83, 227-231. [CrossRef]

125. Nicholson, R.I.; Gee, J.M.W.; Harper, M.E. EGFR and cancer prognosis. Eur. J. Cancer 2001, 37, 9-15. [CrossRef]

126. Hirsch, F.R.; Varella-Garcia, M.; Bunn, P.A., Jr.; Di Maria, M.V.; Veve, R.; Bremmes, R.M.; Baron, A.E.; Zeng, C.; Franklin, W.A. Epidermal growth factor receptor in non-small-cell lung carcinomas: Correlation between gene copy number and protein expression and impact on prognosis. J. Clin. Oncol. 2003, 21, 3798-3807. [CrossRef]

127. Moran, A.E.; Hunt, D.H.; Javid, S.H.; Redston, M.; Carothers, A.M.; Bertagnolli, M.M. Apc deficiency is associated with increased Egfr activity in the intestinal enterocytes and adenomas of C57BL/6J-Min/+ mice. J. Biol. Chem. 2004, 279, 43261-43272. [CrossRef]

128. Vlahovic, G.; Crawford, J. Activation of tyrosine kinases in cancer. Oncologist 2003, 8, 531-538. [CrossRef]

129. Yang, H.; Jiang, D.; Li, W.; Liang, J.; Gentry, L.E.; Brattain, M.G. Defective cleavage of membrane bound TGF $\alpha$ leads to enhanced activation of the EGF receptor in malignant cells. Oncogene 2000, 19, 1901-1914. [CrossRef]

130. Taron, M.; Ichinose, Y.; Rosell, R.; Mok, T.; Massuti, B.; Zamora, L.; Mate, J.L.; Manegold, C.; Ono, M.; Queralt, C.; et al. Activating mutations in the tyrosine kinase domain of the epidermal growth factor receptor are associated with improved survival in gefitinib-treated chemorefractory lung adenocarcinomas. Clin. Cancer Res. 2005, 11, 5878-5885. [CrossRef]

131. Nagahara, H.; Mimori, K.; Ohta, M.; Utsunomiya, T.; Inoue, H.; Barnard, G.F.; Ohira, M.; Hirakawa, K.; Mori, M. Somatic mutations of epidermal growth factor receptor in colorectal carcinoma. Clin. Cancer Res. 2005, 11, 1368-1371. [CrossRef] [PubMed]

132. Pai, R.; Soreghan, B.; Szabo, I.L.; Pavelka, M.; Baatar, D.; Tarnawski, A.S. Prostaglandin E2 transactivates EGF receptor: A novel mechanism for promoting colon cancer growth and gastrointestinal hypertrophy. Nat. Med. 2002, 8, 289-293. [CrossRef] [PubMed]

133. Buchanan, F.G.; Wang, D.; Bargiacchi, F.; DuBois, R.N. Prostaglandin E2 regulates cell migration via the intracellular activation of the epidermal growth factor receptor. J. Biol. Chem. 2003, 278, 35451-35457. [CrossRef] [PubMed]

134. Al-Salihi, M.A.; Terrece Pearman, A.; Doan, T.; Reichert, E.C.; Rosenberg, D.W.; Prescott, S.M.; Stafforini, D.M.; Topham, M.K. Transgenic expression of cyclooxygenase-2 in mouse intestine epithelium is insufficient to initiate tumorigenesis but promotes tumor progression. Cancer Lett. 2009, 273, 225-232. [CrossRef] [PubMed]

135. Fischer, O.M.; Hart, S.; Gschwind, A.; Ullrich, A. EGFR signal transactivation in cancer cells. Biochem. Soc. Trans. 2003, 31, 1203-1208. [CrossRef]

136. Wetzker, R.; Bohmer, F.D. Transactivation joins multiple tracks to the ERK/MAPK cascade. Nat. Rev. Mol. Cell Biol. 2003, 4, 651-657. [CrossRef] [PubMed]

137. Hosur, V.; Low, B.E.; Shultz, L.D.; Wiles, M.V. Genetic deletion of amphiregulin restores the normal skin phenotype in a mouse model of the human skin disease tylosis. Biol. Open 2017, 6, 1174-1179. [CrossRef]

138. Hosur, V.; Farley, M.L.; Burzenski, L.M.; Shultz, L.D.; Wiles, M.V. ADAM17 is essential for ectodomain shedding of the EGF-receptor ligand amphiregulin. FEBS Open Bio 2018, 8, 702-710. [CrossRef]

139. Hosur, V.; Lyons, B.L.; Burzenski, L.M.; Shultz, L.D. Tissue-specific role of RHBDF2 in cutaneous wound healing and hyperproliferative skin disease. BMC Res. Notes 2017, 10, 573. [CrossRef] 
140. Zou, H.; Thomas, S.M.; Yan, Z.-W.; Grandis, J.R.; Vogt, A.; Li, L.-Y. Human rhomboid family-1 gene RHBDF1 participates in GPCR-mediated transactivation of EGFR growth signals in head and neck squamous cancer cells. FASEB J. Off. Publ. Fed. Am. Soc. Exp. Biol. 2009, 23, 425-432. [CrossRef]

141. Roskoski, R., Jr. Small molecule inhibitors targeting the EGFR/ErbB family of protein-tyrosine kinases in human cancers. Pharm. Res. 2019, 139, 395-411. [CrossRef] [PubMed]

142. Kao, J.; Sikora, A.T.; Fu, S. Dual EGFR and COX-2 Inhibition as a novel approach to targeting head and neck squamous cell carcinoma. Curr. Cancer Drug Targets 2009, 9, 931-937. [CrossRef]

143. Habets, R.A.; Groot, A.J.; Yahyanejad, S.; Tiyanont, K.; Blacklow, S.C.; Vooijs, M. Human NOTCH2 is resistant to ligand-independent activation by metalloprotease Adam17. J. Biol. Chem. 2015, 290, 14705-14716. [CrossRef] [PubMed]

144. Bozkulak, E.C.; Weinmaster, G. Selective use of ADAM10 and ADAM17 in activation of Notch1 signaling. Mol. Cell Biol. 2009, 29, 5679-5695. [CrossRef]

145. De Strooper, B.; Annaert, W.; Cupers, P.; Saftig, P.; Craessaerts, K.; Mumm, J.S.; Schroeter, E.H.; Schrijvers, V.; Wolfe, M.S.; Ray, W.J.; et al. A presenilin-1-dependent gamma-secretase-like protease mediates release of Notch intracellular domain. Nature 1999, 398, 518-522. [CrossRef] [PubMed]

146. Schroeter, E.H.; Kisslinger, J.A.; Kopan, R. Notch-1 signalling requires ligand-induced proteolytic release of intracellular domain. Nature 1998, 393, 382-386. [CrossRef]

147. Nowell, C.S.; Radtke, F. Notch as a tumour suppressor. Nat. Rev. Cancer 2017, 17, 145-159. [CrossRef] [PubMed]

148. Restivo, G.; Nguyen, B.C.; Dziunycz, P.; Ristorcelli, E.; Ryan, R.J.; Ozuysal, O.Y.; Di Piazza, M.; Radtke, F.; Dixon, M.J.; Hofbauer, G.F.; et al. IRF6 is a mediator of Notch pro-differentiation and tumour suppressive function in keratinocytes. EMBO J. 2011, 30, 4571-4585. [CrossRef]

149. Sanchez-Martin, M.; Ferrando, A. The NOTCH1-MYC highway toward T-cell acute lymphoblastic leukemia. Blood 2017, 129, 1124-1133. [CrossRef]

150. Chow, J.; Franz, K.M.; Kagan, J.C. PRRs are watching you: Localization of innate sensing and signaling regulators. Virology 2015, 479-480, 104-109. [CrossRef]

151. Akira, S.; Uematsu, S.; Takeuchi, O. Pathogen recognition and innate immunity. Cell 2006, 124, $783-801$. [CrossRef] [PubMed]

152. Schlee, M.; Hartmann, G. Discriminating self from non-self in nucleic acid sensing. Nat. Rev. Immunol. 2016, 16, 566-580. [CrossRef] [PubMed]

153. Yoneyama, M.; Kikuchi, M.; Natsukawa, T.; Shinobu, N.; Imaizumi, T.; Miyagishi, M.; Taira, K.; Akira, S.; Fujita, T. The RNA helicase RIG-I has an essential function in double-stranded RNA-induced innate antiviral responses. Nat. Immunol. 2004, 5, 730-737. [CrossRef] [PubMed]

154. Kawai, T.; Takahashi, K.; Sato, S.; Coban, C.; Kumar, H.; Kato, H.; Ishii, K.J.; Takeuchi, O.; Akira, S. IPS-1, an adaptor triggering RIG-I- and Mda5-mediated type I interferon induction. Nat. Immunol. 2005, 6, 981-988. [CrossRef]

155. Seth, R.B.; Sun, L.; Ea, C.K.; Chen, Z.J. Identification and characterization of MAVS, a mitochondrial antiviral signaling protein that activates NF-kappaB and IRF 3. Cell 2005, 122, 669-682. [CrossRef]

156. Sun, L.; Wu, J.; Du, F.; Chen, X.; Chen, Z.J. Cyclic GMP-AMP synthase is a cytosolic DNA sensor that activates the type I interferon pathway. Science 2013, 339, 786-791. [CrossRef]

157. Xu, L.G.; Wang, Y.Y.; Han, K.J.; Li, L.Y.; Zhai, Z.; Shu, H.B. VISA is an adapter protein required for virus-triggered IFN-beta signaling. Mol. Cell 2005, 19, 727-740. [CrossRef] [PubMed]

158. Hou, F.; Sun, L.; Zheng, H.; Skaug, B.; Jiang, Q.X.; Chen, Z.J. MAVS forms functional prion-like aggregates to activate and propagate antiviral innate immune response. Cell 2011, 146, 448-461. [CrossRef] [PubMed]

159. Sun, Y.; Zheng, H.; Yu, S.; Ding, Y.; Wu, W.; Mao, X.; Liao, Y.; Meng, C.; Ur Rehman, Z.; Tan, L.; et al. Newcastle disease virus $\mathrm{V}$ protein degrades mitochondrial antiviral signaling protein to inhibit host type I interferon production via E3 ubiquitin ligase RNF5. J. Virol. 2019, 93, 18. [CrossRef] [PubMed]

160. Park, Y.J.; Oanh, N.T.K.; Heo, J.; Kim, S.G.; Lee, H.S.; Lee, H.; Lee, J.H.; Kang, H.C.; Lim, W.; Yoo, Y.S.; et al. Dual targeting of RIG-I and MAVS by MARCH5 mitochondria ubiquitin ligase in innate immunity. Cell Signal. 2020, 67, 109520. [CrossRef]

161. Swensson, O.; Langbein, L.; McMillan, J.R.; Stevens, H.P.; Leigh, I.M.; McLean, W.H.; Lane, E.B.; Eady, R.A. Specialized keratin expression pattern in human ridged skin as an adaptation to high physical stress. $\mathrm{Br}$. J. Dermatol. 1998, 139, 767-775. [CrossRef] [PubMed] 
162. Swensson, O.; Eady, R.A. Morphology of the keratin filament network in palm and sole skin: Evidence for site-dependent features based on stereological analysis. Arch. Derm. Res. 1996, 288, 55-62. [CrossRef] [PubMed]

163. Fuchs, E.; Green, H. Changes in keratin gene expression during terminal differentiation of the keratinocyte. Cell 1980, 19, 1033-1042. [CrossRef]

164. Moll, R.; Divo, M.; Langbein, L. The human keratins: Biology and pathology. Histochem. Cell Biol. 2008, 129, 705-733. [CrossRef]

165. Paladini, R.D.; Takahashi, K.; Bravo, N.S.; Coulombe, P.A. Onset of re-epithelialization after skin injury correlates with a reorganization of keratin filaments in wound edge keratinocytes: Defining a potential role for keratin 16. J. Cell Biol. 1996, 132, 381-397. [CrossRef]

166. Karantza, V. Keratins in health and cancer: More than mere epithelial cell markers. Oncogene 2011, 30, 127-138. [CrossRef]

167. McLean, W.H.I.; Rugg, E.L.; Lunny, D.P.; Morley, S.M.; Lane, E.B.; Swensson, O.; Dopping-Hepenstal, P.J.C.; Griffiths, W.A.D.; Eady, R.A.J.; Higgins, C.; et al. Keratin 16 and keratin 17 mutations cause pachyonychia congenita. Nat. Genet. 1995, 9, 273-278. [CrossRef]

(C) 2020 by the authors. Licensee MDPI, Basel, Switzerland. This article is an open access article distributed under the terms and conditions of the Creative Commons Attribution (CC BY) license (http://creativecommons.org/licenses/by/4.0/). 